\title{
Antimicrobial Resistance Mechanisms and Virulence of Colistin- and Carbapenem-Resistant Acinetobacter baumannii Isolated from a Teaching Hospital in Taiwan
}

\author{
Noor Andryan Ilsan ${ }^{1,2}$, Yuarn-Jang Lee ${ }^{3,4}$, Shu-Chen Kuo ${ }^{5}$, I-Hui Lee ${ }^{2,6}$ and Tzu-Wen Huang ${ }^{2,6, *(D)}$ \\ 1 International Master/Ph.D. Program in Medicine, College of Medicine, Taipei Medical University, \\ Taipei 11031, Taiwan; noorandryanilsan@gmail.com \\ 2 Department of Microbiology and Immunology, School of Medicine, College of Medicine, Taipei Medical \\ University, Taipei 11031, Taiwan; sos810712@gmail.com \\ 3 Department of Internal Medicine, Division of Infectious Diseases, Taipei Medical University Hospital, \\ Taipei 11031, Taiwan; yuarn438@yahoo.com.tw \\ 4 Department of Internal Medicine, Division of Infectious Diseases, School of Medicine, College of Medicine, \\ Taipei Medical University, Taipei 11031, Taiwan \\ 5 National Institute of Infectious Diseases and Vaccinology, National Health Research Institutes, \\ Zhunan 35053, Taiwan; sckuo@nhri.edu.tw \\ 6 Graduate Institute of Medical Sciences, College of Medicine, Taipei Medical University, Taipei 11031, Taiwan \\ * Correspondence: tw.huang@tmu.edu.tw; Tel./Fax: +886-2-2736-1661 (ext. 3925); (ext. 3921)
}

\section{check for} updates

Citation: Ilsan, N.A.; Lee, Y.-J.; Kuo, S.-C.; Lee, I-H.; Huang, T.-W.

Antimicrobial Resistance Mechanisms and Virulence of Colistin- and Carbapenem-Resistant Acinetobacter baumannii Isolated from a Teaching Hospital in Taiwan. Microorganisms 2021, 9, 1295. https://doi.org/ 10.3390/microorganisms 9061295

Academic Editors: Matthew Donadu, Donatella Usai and Stefania Zanetti

Received: 24 May 2021

Accepted: 12 June 2021

Published: 14 June 2021

Publisher's Note: MDPI stays neutral with regard to jurisdictional claims in published maps and institutional affiliations.

Copyright: (c) 2021 by the authors. Licensee MDPI, Basel, Switzerland. This article is an open access article distributed under the terms and conditions of the Creative Commons Attribution (CC BY) license (https:// creativecommons.org/licenses/by/ $4.0 /)$.
Abstract: Acinetobacter baumannii, a Gram-negative bacterium, is an important nosocomial pathogen. Colistin-resistant $A$. baumannii is becoming a new concern, since colistin is one of the last-line antibiotics for infections by carbapenem-resistant $A$. baumannii. From 452 carbapenem-resistant isolates collected in a teaching hospital in Taipei, Taiwan, we identified seven that were resistant to colistin. Carbapenem resistance in these isolates is attributed to the presence of carbapenemase gene $b l a_{\mathrm{OXA}-23}$ in their genomes. Colistin resistance is presumably conferred by mutations in the sensor kinase domain of PmrB found in these isolates, which are known to result in modification of colistin target lipid A via the PmrB-PmrA-PmrC signal transduction pathway. Overexpression of $p m r C$, ept $A$, and naxD was observed in all seven isolates. Colistin resistance mediated by pmrB mutations has never been reported in Taiwan. One of the seven isolates contained three mutations in $l p x D$ and exhibited an altered lipopolysaccharide profile, which may contribute to its colistin resistance. No significant difference in growth rates was observed between the isolates and the reference strain, suggesting no fitness cost of colistin resistance. Biofilm formation abilities of the isolates were lower than that of the reference. Interestingly, one of the isolates was heteroresistant to colistin. Four of the isolates were significantly more virulent to wax moth larvae than the reference.

Keywords: nosocomial pathogen; whole-genome sequencing; two-component system; lipopolysaccharide; phosphoethanolamine transferase; biofilm; heteroresistance; Galleria mellonella

\section{Introduction}

The global increase in antimicrobial resistance (AMR) among pathogenic bacteria threatens human health. Deaths caused by antimicrobial-resistant bacteria are expected to exceed deaths caused by cancers in 2050 if the increase of AMR is not controlled [1,2]. Currently, many pathogenic bacteria are highly prevalent on antimicrobial resistance in many countries. Clinical doctors are frequently forced to use second-line or last-line antibiotics for bacterial infections. Consequently, more multidrug- or even pandrugresistant bacteria have emerged [3]. Carbapenem resistance is a particularly critical case. The World Health Organization has listed carbapenem-resistant Gram-negative bacilli including Acinetobacter baumannii, Pseudomonas aeruginosa, and Enterobacteriaceae as critical pathogens for which discovery and development of new antibiotics are of urgent priority due to limited treatment options available for infection by these bacteria [4]. 
A. baumannii is a predominant pathogen associated with nosocomial and community infections at various body sites including the bloodstream, respiratory tract, urinary tract, surgical sites, and wounds [5]. Due to the difficulty in species identification, three clinically relevant species, $A$. baumannii, Acinetobacter nosocomialis, and Acinetobacter pittii, are grouped with an environmental species, Acinetobacter calcoaceticus, into the $A$. calcoaceticusA. baumannii (Acb) complex [6]. This group of bacteria pose a high challenge in clinical settings because of their high AMR [6]. The development of multidrug resistance (MDR) in A. baumannii is mediated through genomic mutations or acquired antimicrobial resistance genes. Carbapenem treatment for MDR A. baumannii infections leads to an increase in the prevalence of carbapenem-resistant A. baumannii (CRAB). A longitudinal surveillance program in Taiwan showed an increase of CRAB prevalence from $3.4 \%$ in 2002 to $58.7 \%$ in 2012 [7]. The frequency of CRAB was approximately $70 \%$ in the Acb complex isolated from hospitals in Taiwan [8]. A 2019 report from the Centers for Disease Control in the United States listed CRAB as an urgent threat to public health [9]. Because of the significant increase in $\mathrm{CRAB}$, colistin has been used to treat $\mathrm{CRAB}$ infections despite its nephrotoxicity. Eventually and not unexpectedly, the emergence of colistin- and carbapenem-resistant $A$. baumannii (CCR-AB) was reported [10-12].

Colistin is a cationic lipopeptide that interacts directly with lipid A of lipopolysaccharide (LPS). Insertion of colistin inside the outer membrane of Gram-negative bacteria results in membrane disruption and cell death [13]. Mechanisms of colistin resistance in $A$. baumannii are mainly caused by chemical modifications of LPS mediated through dysregulation or acquisition of LPS modifying enzymes [14-16]. Mutations in the two-component system, $\operatorname{pmr} A$ (response regulator) and $\operatorname{pmr} B$ (kinase sensor), result in upregulation of the downstream gene $p m r C$, which encodes a lipid A phosphoethanolamine (pEtN) transferase. Overproduction of PmrC increases the addition of pEtN to lipid A, lowering its affinity to colistin [17-20]. Overexpression of other LPS modifying enzymes, such as EptA (PmrC homolog) and NaxD (acetyl-galactosamine deacetylase), which are under pmr $A B$ regulation, has also been reported to confer colistin resistance $[19,21]$. Recently, plasmid-borne pEtN transferases, Mcr-1 and Mcr-4.3, were found in A. baumannii [14,15]. Mutations in LPS biosynthesis genes, such as $\operatorname{lp} x A, \operatorname{lp} x C$, and $\operatorname{lp} x D$ (lipid A) [22,23] or lpsB or $l p t D$ (nonlipid A) [24,25], may also confer colistin resistance. Other colistin resistance mechanisms include reduction of biosynthesis of osmoprotective amino acids or expression of efflux pumps $[24,26,27]$.

Alteration of LPS structure may change the fitness of the CCR-AB cultures and their virulence. Impaired virulence and in vivo fitness were observed in a laboratory-evolved colistin-resistant strain of $A$. baumannii with a $p m r B$ mutation [28] or in a clinical isolate from a patient without signs of infection [29]. A strong cost of fitness and virulence was found in colistin resistance with LPS loss rather than with LPS modification in A. baumannii [30,31]. In contrast, there have been reports showing no reduction in the growth or virulence in colistin-resistant $A$. baumannii $[32,33]$.

A meta-analysis showed that the highest prevalence of colistin resistance in $A$. baumannii was in Lebanon (17.5\%) followed by China (12\%) among 41 countries surveyed [34]. The increasing trend of colistin resistance from 2000 to 2017 was higher in South-East Asia and the Eastern Mediterranean than in Europe and Africa [34]. The prevalence of colistinresistant $A$. baumannii in Taiwan was $2.5 \%$ according to a meta-analysis spanning from 2013 to 2016 [34]. Different collections from Taiwan showed various degrees of colistin-resistant A. baumannii. A national surveillance from Intensive Care Units in Taiwan reported the prevalence as 6\% in 2005 and 10.1\% in 2016 [35,36]. Another study in 2007 showed the prevalence was $10.4 \%$ across Eastern, Southern, and Northern Taiwan [37]. None of these reports have explored the molecular characteristics and resistance mechanisms of the colistin-resistant $A$. baumannii isolates.

In this study, we collected CRAB from a teaching hospital in Taiwan from 2017 to 2018. The prevalence of colistin resistance was $1.5 \%$ among the CRAB isolates. Seven CCR-AB isolates were identified and chosen for characterization at the molecular level including 
multilocus sequence types, capsule types, and resistome profiles. In addition, mechanisms of colistin resistance were investigated. Heteroresistance to colistin was found in one of the seven isolates. Virulence-associated phenotypes such as growth, biofilm formation, and virulence in a wax moth infection model were studied.

\section{Materials and Methods}

2.1. Collection of Clinical Isolates, Species Identification, and Antimicrobial Susceptibility Testing

Carbapenem-resistant Acb isolates were collected at Taipei Medical University Hospital from 2017 to 2018. From them, seven isolates resistant to colistin and carbapenem were further characterized. Antimicrobial susceptibility testing (AST) was performed using BD Phoenix ${ }^{\mathrm{TM}}$ Automated Identification and Susceptibility Testing System (BD Diagnostics System, Sparks, MD, USA). Validation of colistin resistance was performed using the broth microdilution method in cation-adjusted Mueller-Hinton broth. Interpretation of AST was based on the criteria of Clinical \& Laboratory Standards Institute (CLSI) guideline 2018 [38]. Species identification was based on $g y r B$ multiplex PCR [39] supplemented by rpoB PCR and sequencing. Detection of oxacillinase genes including bla $a_{\mathrm{OXA}-51}, b l a_{\mathrm{OXA}-23}, b l a_{\mathrm{OXA}-24}$, and $b l a_{\text {OXA-58 }}$ was performed using PCR. The PCR primers are listed in Table S1.

\subsection{Whole-Genome Sequencing and Molecular Characterization}

Genomic DNA was extracted from overnight cultures in tryptic soy broth at $37^{\circ} \mathrm{C}$ using a Wizard Genomic DNA Purification Kit (Promega, Madison, WI, USA). Whole-genome sequencing was performed using the Illumina platform with a read length of $150 \mathrm{bp}$ in pairs. The depth of each isolate was over 30. The obtained short reads of each isolate were assembled de novo using CLC Genome Workbench (QIAGEN, Hilden, Germany). The numbers of contigs for each isolate ranged from 187 to 494 . The assembled draft genomes were used to determine molecular features. Two schemes of MLSTs, Pasteur [40] and Oxford [41], were analyzed using MLST 2.0 (https: / / cge.cbs.dtu.dk/services/MLST/, accessed on 21 July 2020). Capsule types were determined using Kaptive [42]. Acquired antimicrobial resistance genes were detected with coverage $>60 \%$ and identity $>90 \%$ using ResFinder 3.2 [43]. Draft genomes of these isolates have been deposited at the National Center for Biotechnology Information with the following accession numbers: JAENTF000000000 (T1060317), JAENTE000000000 (T1060361), JAENTD000000000 (T1060578), JAENTC000000000 (T1060580), JAENTB000000000 (T1070171), JAENTA000000000 (T1070213), and JAENSZ000000000 (T1070678).

\subsection{Sequence Analysis of Genes Related to Colistin Resistance and Virulence}

Sequences of genes related to virulence and colistin resistance in each isolate were compared pairwise with the reference strain (A. baumannii ACICU). Common genes related to colistin resistance including $p m r C A B$ operon, $\operatorname{lp} x A, \operatorname{lp} x C$, and $\operatorname{lp} x D$ were analyzed by BLAST and validated by PCR sequencing (primers listed in Table S1). Other reported genes (pheS, pldA, vacJ, IpsB, and miaA) were also examined by sequence comparison with the reference strain. Virulence genes were detected on the Virulence Factors Database (VFDB) server [44]. The criteria of BLASTN analysis were score $>100$ and identity $>90 \%$.

\subsection{Detection of Gene Expression Levels}

The expression levels of $\operatorname{pmrC}$, ept $A$, and naxD were determined using reverse transcriptase quantitative PCR. Bacterial cultures in exponential phase $\left(\mathrm{OD}_{600}\right.$ of $\left.0.5 \sim 0.7\right)$ were harvested and treated with RNAlater ${ }^{\mathrm{TM}}$ solution (Thermo Fisher Scientific, Carlsbad, CA, USA) for one hour at room temperature. Total RNA was extracted using PureLink ${ }^{\mathrm{TM}}$ RNA Mini Kit (Thermo Fisher Scientific, Carlsbad, CA, USA). DNA was eliminated by DNase I (Lucigen Corporation, Middleton, WI, USA) treatment. RNA was further purified using RNA Clean and Concentrator ${ }^{\mathrm{TM}}-5$ (Zymo Research, Irvine, CA, USA). Concentration of total RNA was measured using NanoDrop ${ }^{\circledR}$ ND-1000 spectrophotometer (Thermo Fisher Scientific, Waltham, MA, USA) and integrity of RNA was evaluated using agarose gel electrophoresis. Complementary DNA was synthesized using High-capacity cDNA Re- 
verse Transcription Kits (Applied Biosystems, Waltham, MA, USA). Three targeted genes (ept $A, n a x D$, and $p m r C)$ and the reference gene $(r p o B)$ were quantified using SensiFAST ${ }^{\mathrm{TM}}$ SYBR $^{\circledR}$ Hi-ROX Kit (Meridian Bioscience, Cincinnati, OH, USA) with respective primer pairs (listed in Table S1) in Applied Biosystems 7300 Real-Time PCR System (Thermo Fisher Scientific, Waltham, MA, USA). Relative expression levels were determined using the $2^{-\Delta \Delta \mathrm{Ct}}$ method [45]. A. baumannii ATCC 19606 was chosen as the reference. Statistical significances between the CCR-AB isolates and the reference were calculated using one-way ANOVA. Statistical analyses and graphs were produced using GraphPad Prism 5.

\subsection{Lipopolysaccharide Analysis by SDS-PAGE}

LPS extraction from overnight bacterial cultures on LB agar was performed using an LPS Extraction Kit (Abcam, Cambridge, UK). The extracted LPS was mixed in 2X SDS loading buffer, boiled for $15 \mathrm{~min}$, and subjected to SDS-PAGE in 15\% acrylamide gels. After electrophoresis, the gel was stained with silver stain.

\subsection{Measurement of Generation Time}

An overnight bacterial culture in Mueller-Hinton broth (MHB) was harvested and adjusted to $\mathrm{OD}_{600} 0.1$. The $250 \mu \mathrm{L}$ of diluted suspension was inoculated into $50 \mathrm{~mL} \mathrm{MHB}$ in a 250 -mL flask and shaken at 150 r.p.m. at $37^{\circ} \mathrm{C}$. $\mathrm{OD}_{600}$ value was measured every $30 \mathrm{~min}$ until the end of the exponential phase. Log phase determinations were used to calculate the generation time [46].

\subsection{Biofilm Formation Ability}

Biofilm formation was assessed either by static culture in a 96-well polystyrene microplate or aerated culture with a plate covered by a lid with pegs. Biofilm was measured using the crystal violet method [47]. For measurement of biofilm production in static cultures, each isolate was cultured in $3 \mathrm{~mL} \mathrm{MHB}$ for $16 \mathrm{~h}$ at $37^{\circ} \mathrm{C}$. The cultures were adjusted to $\mathrm{OD}_{600}$ of 0.01 , and $100 \mu \mathrm{L}$ of the dilution was transferred into a 96 -well polystyrene microplate (eight replicate wells per isolate) and incubated at $37^{\circ} \mathrm{C}$ for $24 \mathrm{~h}$ without shaking. After removal of the bacterial cultures, the wells were washed with sterile water, stained with $150 \mu \mathrm{L}$ of $0.1 \%(w / v)$ crystal violet at room temperature for $30 \mathrm{~min}$, washed three times with water, and then air-dried. For measurement of biofilm formation in aerated cultures, $200 \mu \mathrm{L}$ of diluted suspension was aliquoted into an MBEC assay ${ }^{\circledR}$ biofilm inoculator with a 96-well base (Innovotech, Edmonton, Canada) and shaken at 110 r.p.m. for $16 \mathrm{~h}$ in a $37^{\circ} \mathrm{C}$ incubator. Biofilm formed on the pegs was rinsed with water three times, stained in $200 \mu \mathrm{L}$ of $0.1 \%(w / v)$ crystal violet at room temperature for $30 \mathrm{~min}$, washed with water, and dried. The stained biofilm was dissolved in 33\% acetic acid solution and absorbance at $550 \mathrm{~nm}$ was measured in a spectrophotometer. ATCC 19606 served as a positive control and MHB blank as a negative control. Statistical significances were determined by one-way ANOVA. Statistical analyses and graphs were constructed using GraphPad Prime 5.

\subsection{Determination of Colistin Heteroresistance}

Bacterial isolates were cultured in $3 \mathrm{~mL}$ LB broth in an orbital shaker at 150 r.p.m. at $37^{\circ} \mathrm{C}$ for $16-20 \mathrm{~h}$. The overnight cultures were serially diluted from $10^{1}$ to $10^{7}$ folds. The diluted suspensions were spread onto LB agar plates containing colistin in concentrations ranging from 0 to $128 \mathrm{mg} / \mathrm{L}$ in 2-fold increments and incubated at $37^{\circ} \mathrm{C}$ for $16 \mathrm{~h}$. Colony formation units (CFU) on the agar plates were counted. The fraction of colistin-resistant bacteria at each concentration was determined by dividing them into CFU on colistin-free agars. Isolates that exhibited a resistance fraction between $10^{-7}$ and $5 \times 10^{-1}$ at $16 \mathrm{mg} / \mathrm{L}$ of colistin were designated heteroresistant [48]. 


\subsection{Virulence Analysis in Galleria Mellonella Infection Model}

A $1.5 \mathrm{~mL}$ aliquot of overnight culture in LB was centrifuged and the pellet was resuspended into $500 \mu \mathrm{L}$ PBS. The suspension was adjusted to $\mathrm{OD}_{600}$ of 0.01 (approximately $10^{7} \mathrm{CFU} / \mathrm{mL}$ ). Late-stage larvae of wax moth Galleria mellonella reared in-house at $28^{\circ} \mathrm{C}$ were harvested. Fifteen larvae weighing $250-350 \mathrm{mg}$ were injected at the last left proleg with $10 \mu \mathrm{L}$ of the bacterial suspension using a needle syringe [49]. Survival of the larvae was scored after 24, 48, and $72 \mathrm{~h}$. A reference strain, A. baumannii AYE, and PBS solution were used as positive and negative controls, respectively. The Kaplan-Meier survival curve and statistical analysis were constructed using GraphPad Prism 5.

\section{Results and Discussion}

\subsection{Epidemiology of Colistin- and Carbapenem-Resistant A. baumannii (CCR-AB)}

Seven of our 452 CRAB isolates from 2017 to 2018 collected from sputum specimens of five hospitalized patients were resistant to colistin. The CCR-AB prevalence $(1.5 \%)$ was significantly lower than that previously reported in Taiwan (10.4\% in 2007 [37] and $10.1 \%$ in 2016 [36]) and in Greece (32.8\% in 2015-2017) [50]. The antimicrobial susceptibility of the seven isolates is shown in Table 1. While one isolate (T1060587) exhibited multidrug resistance (MDR), the remaining six were extensively drug-resistant (XDR). All were sensitive to minocycline and resistant to colistin, imipenem, meropenem, gentamicin, and ciprofloxacin. Minimal inhibitory concentration of colistin ranging from 0.5 to $16 \mathrm{mg} / \mathrm{L}$ was reported for previous isolates in Taiwan [36]. However, high resistance to colistin, i.e., at least an eight-fold increase in the breakpoint, was observed in our isolates.

Table 1. Antimicrobial susceptibility testing of the CCR-AB isolates.

\begin{tabular}{|c|c|c|c|c|c|c|c|c|c|c|c|c|c|c|c|c|c|}
\hline \multirow{2}{*}{ Isolate } & \multirow{2}{*}{ Isolation Date } & \multirow{2}{*}{$\begin{array}{l}\text { Patient } \\
\text { ID }\end{array}$} & \multicolumn{15}{|c|}{ Minimal Inhibition Concentration $(\mathrm{mg} / \mathrm{L})^{1}$} \\
\hline & & & IMP & MEM & CTX & CAZ & CRO & FEP & SAM & TZP & GEN & AMK & CIP & LVX & SXT & $\mathrm{COL}^{2}$ & MIN \\
\hline T1060317 & 11 July 2017 & РT0044 & $\begin{array}{l}>4 \\
(\mathrm{R})\end{array}$ & $\begin{array}{l}>4 \\
(\mathrm{R})\end{array}$ & $\begin{array}{l}>32 \\
(\mathrm{R})\end{array}$ & $\begin{array}{l}>16 \\
(\mathrm{R})\end{array}$ & $\begin{array}{l}>32 \\
(\mathrm{R})\end{array}$ & $\begin{array}{l}>16 \\
(\mathrm{R})\end{array}$ & $\begin{array}{c}>16 / 8 \\
(\mathrm{R})\end{array}$ & $\begin{array}{l}>64 / 4 \\
\text { (R) }\end{array}$ & $\begin{array}{l}>8 \\
(\mathrm{R})\end{array}$ & $\begin{array}{l}>32 \\
(\mathrm{R})\end{array}$ & $\begin{array}{l}>2 \\
(\mathrm{R})\end{array}$ & $\begin{array}{l}>4 \\
(\mathrm{R})\end{array}$ & $\begin{array}{l}>2 / 38 \\
(\mathrm{R})\end{array}$ & $\begin{array}{l}>128 \\
(\mathrm{R})\end{array}$ & $\begin{array}{c}4 \\
(\mathrm{~S})\end{array}$ \\
\hline T1060361 & 25 July 2017 & РT0044 & $\begin{array}{l}>4 \\
(\mathrm{R}) \\
\end{array}$ & $\begin{array}{l}>4 \\
(\mathrm{R}) \\
\end{array}$ & $\begin{array}{l}>32 \\
(\mathrm{R})\end{array}$ & $\begin{array}{l}>16 \\
(\mathrm{R})\end{array}$ & $\begin{array}{l}>32 \\
(\mathrm{R})\end{array}$ & $\begin{array}{l}>16 \\
(\mathrm{R})\end{array}$ & $\begin{array}{c}>16 / 8 \\
\text { (R) }\end{array}$ & $\begin{array}{l}>64 / 4 \\
\text { (R) }\end{array}$ & $\begin{array}{l}>8 \\
(\mathrm{R})\end{array}$ & $\begin{array}{l}>32 \\
(\mathrm{R})\end{array}$ & $\begin{array}{l}>2 \\
(\mathrm{R})\end{array}$ & $\begin{array}{l}>4 \\
(\mathrm{R}) \\
\end{array}$ & $\begin{array}{l}>2 / 38 \\
(\mathrm{R})\end{array}$ & $\begin{array}{l}128 \\
(\mathrm{R})\end{array}$ & $\begin{array}{c}4 \\
(\mathrm{~S}) \\
\end{array}$ \\
\hline T1060578 & $\begin{array}{c}10 \text { November } \\
2017\end{array}$ & PT0345 & $\begin{array}{l}>4 \\
(\mathrm{R})\end{array}$ & $\begin{array}{l}>4 \\
(\mathrm{R})\end{array}$ & $\begin{array}{c}8 \\
(\mathrm{~S})\end{array}$ & $\begin{array}{c}2 \\
(S)\end{array}$ & $\begin{array}{c}4 \\
(\mathrm{~S})\end{array}$ & $\begin{array}{c}8 \\
(\mathrm{~S})\end{array}$ & $\begin{array}{l}8 / 4 \\
(\mathrm{~S})\end{array}$ & $\begin{array}{l}64 / 4 \\
\text { (I) }\end{array}$ & $\begin{array}{l}>8 \\
(\mathrm{R})\end{array}$ & $\begin{array}{l}>32 \\
(\mathrm{R})\end{array}$ & $\begin{array}{l}>2 \\
(\mathrm{R})\end{array}$ & $\begin{array}{c}4 \\
\text { (I) }\end{array}$ & $\begin{array}{l}\leq 0.5 / 9.5 \\
\text { (S) }\end{array}$ & $\begin{array}{l}64 \\
(\mathrm{R})\end{array}$ & $\begin{array}{c}4 \\
(\mathrm{~S})\end{array}$ \\
\hline T1060580 & $\begin{array}{l}13 \text { November } \\
2017\end{array}$ & РT0348 & $\begin{array}{l}>4 \\
(\mathrm{R})\end{array}$ & $\begin{array}{l}>4 \\
(\mathrm{R})\end{array}$ & $\begin{array}{l}>32 \\
(\mathrm{R})\end{array}$ & $\begin{array}{l}16 \\
(\mathrm{I})\end{array}$ & $\begin{array}{l}>32 \\
(\mathrm{R})\end{array}$ & $\begin{array}{l}16 \\
(\mathrm{I})\end{array}$ & $\begin{array}{l}8 / 4 \\
(S)\end{array}$ & $\begin{array}{l}64 / 4 \\
(\mathrm{I})\end{array}$ & $\begin{array}{l}>8 \\
(\mathrm{R})\end{array}$ & $\begin{array}{l}>32 \\
(\mathrm{R})\end{array}$ & $\begin{array}{l}>2 \\
(\mathrm{R})\end{array}$ & $\begin{array}{l}>4 \\
(\mathrm{R})\end{array}$ & $\begin{array}{l}>2 / 38 \\
(\mathrm{R})\end{array}$ & $\begin{array}{c}>128 \\
(\mathrm{R})\end{array}$ & $\begin{array}{c}4 \\
(\mathrm{~S}) \\
\end{array}$ \\
\hline T1070171 & 13 March 2018 & PT0512 & $\begin{array}{l}>4 \\
(\mathrm{R})\end{array}$ & $\begin{array}{l}>4 \\
(\mathrm{R})\end{array}$ & $\begin{array}{l}>32 \\
(\mathrm{R})\end{array}$ & $\begin{array}{l}>16 \\
(\mathrm{R})\end{array}$ & $\begin{array}{l}>32 \\
(\mathrm{R})\end{array}$ & $\begin{array}{l}>16 \\
\text { (R) }\end{array}$ & $\begin{array}{c}>16 / 8 \\
(\mathrm{R})\end{array}$ & $\begin{array}{l}>64 / 4 \\
(\mathrm{R})\end{array}$ & $\begin{array}{l}>8 \\
(\mathrm{R})\end{array}$ & $\begin{array}{l}>32 \\
(\mathrm{R})\end{array}$ & $\begin{array}{l}>2 \\
(\mathrm{R})\end{array}$ & $\begin{array}{l}>4 \\
(\mathrm{R})\end{array}$ & $\begin{array}{l}>2 / 38 \\
\text { (R) }\end{array}$ & $\begin{array}{l}>128 \\
(\mathrm{R})\end{array}$ & $\begin{array}{c}4 \\
(\mathrm{~S})\end{array}$ \\
\hline T1070213 & 30 March 2018 & PT0512 & $\begin{array}{l}>4 \\
(\mathrm{R})\end{array}$ & $\begin{array}{l}>4 \\
(\mathrm{R})\end{array}$ & $\begin{array}{l}>32 \\
(\mathrm{R})\end{array}$ & $\begin{array}{l}>16 \\
\text { (R) }\end{array}$ & $\begin{array}{l}>32 \\
(\mathrm{R})\end{array}$ & $\begin{array}{l}>16 \\
(\mathrm{R})\end{array}$ & $\begin{array}{c}>16 / 8 \\
(\mathrm{R})\end{array}$ & $\begin{array}{l}>64 / 4 \\
\text { (R) }\end{array}$ & $\begin{array}{l}>8 \\
(\mathrm{R})\end{array}$ & $\begin{array}{l}\leq \\
8 \\
(\mathrm{~S})\end{array}$ & $\begin{array}{l}>2 \\
(\mathrm{R})\end{array}$ & $\begin{array}{l}>4 \\
(\mathrm{R})\end{array}$ & $\begin{array}{l}>2 / 38 \\
(\mathrm{R})\end{array}$ & $\begin{array}{l}>128 \\
(\mathrm{R})\end{array}$ & $\begin{array}{c}4 \\
(S)\end{array}$ \\
\hline T1070678 & 23 October 2018 & PT0712 & $\begin{array}{l}>4 \\
\text { (R) }\end{array}$ & $\begin{array}{l}>4 \\
(\mathrm{R})\end{array}$ & $\begin{array}{l}>32 \\
\text { (R) }\end{array}$ & $\begin{array}{l}>16 \\
\text { (R) }\end{array}$ & $\begin{array}{l}>32 \\
\text { (R) }\end{array}$ & $\begin{array}{l}>16 \\
\text { (R) }\end{array}$ & $\begin{array}{l}8 / 4 \\
(\mathrm{~S})\end{array}$ & $\begin{array}{l}>64 / 4 \\
\text { (R) }\end{array}$ & $\begin{array}{l}>8 \\
(\mathrm{R})\end{array}$ & $\begin{array}{l}>32 \\
\text { (R) }\end{array}$ & $\begin{array}{l}>2 \\
\text { (R) }\end{array}$ & $\begin{array}{l}>4 \\
\text { (R) }\end{array}$ & $\begin{array}{l}>2 / 38 \\
\text { (R) }\end{array}$ & $\begin{array}{l}64 \\
\text { (R) }\end{array}$ & $\begin{array}{c}4 \\
(S)\end{array}$ \\
\hline
\end{tabular}

1 Abbreviations of tested antibiotics: IMP, imipenem; MEM, meropenem; CTX, cefotaxime; CAZ, ceftazidime; CRO, ceftriaxone; FEP, cefepime; SAM, ampicillin-sulbactam; TZP, piperacillin-tazobactam; GEN, gentamicin; AMK, amikacin; CIP, ciprofloxacin; LVX, levofloxacin; SXT, trimethoprim-sulfamethoxazole; COL, colistin; MIN, minocycline. ${ }^{2}$ Minimal inhibition concentration of colistin was confirmed using the broth microdilution method.

\subsection{Molecular Characterizations of CCR-AB Isolates}

Draft genomes of the seven isolates were determined from which molecular typing and resistome analysis were performed (Table 2). Three groups may be classified based on their molecular characteristics. Sequence types (STs) of the six XDR isolates were ST2 (Pasteur) or alternatively global clone 2 (GC2), with KL2 capsule type. Among them, two isolates (T1060317 and T1060361) from the same patient were ST544 and unknown ST, and the other four were ST208 and ST1806 due to the presence of two $g d h B$ alleles in the Oxford MLST scheme. The MDR isolate was ST136 (Pasteur) with KL107 capsule type, but a novel sequence type was identified near ST460 or ST1092 in the Oxford MLST scheme. 
Table 2. Molecular characterizations and acquired antimicrobial resistance genes in the CCR-AB isolates.

\begin{tabular}{|c|c|c|c|c|c|c|c|c|c|}
\hline \multirow{2}{*}{ Isolate } & \multirow{2}{*}{ Patient ID } & \multirow{2}{*}{$\begin{array}{c}\mathrm{ST}^{1} \\
\text { (Pasteur/Oxford) }\end{array}$} & \multirow{2}{*}{$\begin{array}{l}\text { Capsule } \\
\text { Type }\end{array}$} & \multicolumn{6}{|c|}{ Acquired Resistance Genes } \\
\hline & & & & $\beta$-lactams & Aminoglycosides & Macrolides & Phenicols & Sulfonamides & Tetracyclines \\
\hline T1060317 & РT0044 & $\begin{array}{l}2 / 544 \text { and } \\
\text { unknown }\end{array}$ & KL2 & $\begin{array}{l}b^{b l a_{\mathrm{ADC}-25}} \\
\text { bla }_{\mathrm{OXA}-23} \\
\text { bla }_{\mathrm{OXA}-66} \\
\text { bla }_{\mathrm{TEM}-1 \mathrm{D}}\end{array}$ & $\begin{array}{c}\operatorname{aac}\left(6^{\prime}\right)-I b 3, \text { aad } A 1, \\
\operatorname{aph}\left(3^{\prime \prime}\right)-I b \\
\operatorname{aph}\left(3^{\prime}\right)-I a, \\
\operatorname{aph}\left(6^{\prime}\right)-I d, \operatorname{arm} A\end{array}$ & $\begin{array}{l}\operatorname{mph}(E) \\
m s r(E)\end{array}$ & catB8 & sul1, sul2 & $\operatorname{tet}(B)$ \\
\hline T1060361 & РT0044 & $\begin{array}{l}2 / 544 \text { and } \\
\text { unknown }\end{array}$ & KL2 & $\begin{array}{l}b^{b l a_{\mathrm{ADC}-25}} \\
\text { bla }_{\mathrm{OXA}-23} \\
\text { bla }_{\mathrm{OXA}-66} \\
\text { bla }_{\mathrm{TEM}-1 \mathrm{D}}\end{array}$ & $\begin{array}{c}\operatorname{aac}\left(6^{\prime}\right)-I b 3, \operatorname{aad} A 1, \\
\operatorname{aph}\left(3^{\prime \prime}\right)-I b \\
a p h\left(3^{\prime}\right)-I a, \\
\operatorname{aph}\left(6^{\prime}\right)-I d, \operatorname{arm} A\end{array}$ & $\begin{array}{l}\operatorname{mph}(E) \\
m s r(E)\end{array}$ & catB8 & sul1, sul2 & $\operatorname{tet}(B)$ \\
\hline T1060578 & РT0345 & $\begin{array}{c}136 / \sim 460 \text { or } \\
1092^{2}\end{array}$ & KL107 & $\begin{array}{l}\text { bla }_{\mathrm{ADC}-25} \\
\text { bla }_{\mathrm{OXA}-23} \\
\text { bla }_{\mathrm{OXA}-317}\end{array}$ & $\begin{array}{l}\operatorname{ant}\left(2^{\prime \prime}\right)-I a, \\
\operatorname{aph}\left(3^{\prime}\right)-V I\end{array}$ & - & - & - & - \\
\hline T1060580 & РT0348 & $\begin{array}{l}2 / 208 \text { and } \\
1806\end{array}$ & KL2 & $\begin{array}{l}b l a_{\mathrm{ADC}-25} \\
\text { bla }_{\mathrm{OXA}-23} \\
\text { bla }_{\text {OXA-66, }} \\
\text { bla }_{\mathrm{TEM}-1 \mathrm{D}}\end{array}$ & $\begin{array}{c}\operatorname{aac}\left(6^{\prime}\right)-I b 3, \text { aadA1, } \\
\text { aph }\left(3^{\prime \prime}\right)-I b, \\
\text { aph }\left(3^{\prime}\right)-I a, \\
\text { aph }\left(6^{\prime}\right)-I d, \text { arm } A, \\
\text { ant }\left(2^{\prime \prime}\right)-I a \\
\operatorname{aph}\left(3^{\prime}\right)-V I\end{array}$ & $\begin{array}{l}\operatorname{mph}(E) \\
m s r(E)\end{array}$ & catB8 & sul1, sul2 & $\operatorname{tet}(B)$ \\
\hline T1070171 & PT0512 & $\begin{array}{l}2 / 208 \text { and } \\
1806\end{array}$ & KL2 & $\begin{array}{l}b^{b l a_{\mathrm{ADC}-25}} \\
\text { bla }_{\mathrm{OXA}-23} \\
\text { bla }_{\mathrm{OXA}-66} \\
\text { bla }_{\mathrm{TEM}-1 \mathrm{D}}\end{array}$ & $\begin{array}{c}\operatorname{aac}\left(6^{\prime}\right)-I b 3, \text { aad } A 1, \\
\operatorname{aph}\left(3^{\prime \prime}\right)-I b, \\
\operatorname{aph}\left(3^{\prime}\right)-I a, \\
\operatorname{aph}\left(6^{\prime}\right)-I d, \operatorname{arm} A\end{array}$ & $\begin{array}{l}\operatorname{mph}(E) \\
m s r(E)\end{array}$ & catB8 & sul1, sul2 & $\operatorname{tet}(B)$ \\
\hline T1070213 & РT0512 & $\begin{array}{l}2 / 208 \text { and } \\
1806\end{array}$ & KL2 & $\begin{array}{l}b^{b l a_{\mathrm{ADC}-25}} \\
\text { bla }_{\mathrm{OXA}-23} \\
\text { bla }_{\mathrm{OXA}-66} \\
\text { bla }_{\mathrm{TEM}-1 \mathrm{D}}\end{array}$ & $\begin{array}{l}\operatorname{aph}\left(3^{\prime \prime}\right)-I b \\
\text { aph }\left(6^{\prime}\right)-I d \\
\operatorname{ant}\left(2^{\prime \prime}\right)-I a \\
\operatorname{aph}\left(3^{\prime}\right)-V I\end{array}$ & - & - & sul2 & $\operatorname{tet}(B)$ \\
\hline T1070678 & PT0712 & $\begin{array}{l}2 / 208 \text { and } \\
1806\end{array}$ & KL2 & $\begin{array}{l}\text { bla }_{\mathrm{ADC}-25} \\
\text { bla }_{\mathrm{OXA}-23} \\
\text { bla }_{\mathrm{OXA}-66} \\
\text { bla }_{\mathrm{TEM}-1 \mathrm{D}}\end{array}$ & $\begin{array}{c}\text { aac }\left(6^{\prime}\right)-I b 3, \text { aadA1, } \\
\operatorname{aph}\left(3^{\prime \prime}\right)-I b, \\
a p h\left(3^{\prime}\right)-I a, \\
\operatorname{aph}\left(6^{\prime}\right)-I d, \operatorname{arm} A\end{array}$ & $\begin{array}{l}\operatorname{mph}(E) \\
m s r(E)\end{array}$ & catB8 & sul1, sul2 & $\operatorname{tet}(B)$ \\
\hline
\end{tabular}

${ }^{1}$ ST: Sequence types from both Pasteur and Oxford schemes of multilocus sequence types in A. baumannii. ${ }^{2}$ The symbol " $\sim$ " means the nearest ST.

Acquired resistome analysis showed the presence of OXA-23 oxacillinase hydrolyzing carbapenems in all seven isolates. In addition, all six GC2 isolates except T1070213 harbored nearly identical antimicrobial resistance genes (ARGs) for $\beta$-lactams, aminoglycosides, macrolides, phenicols, sulfonamides, and tetracyclines. T1070213 lacked the ARGs for macrolides and phenicols. However, the ST136 (Pasteur) isolate only contained ARGs for $\beta$-lactams and aminoglycosides. This finding was consistent with its MDR phenotype. In addition, this MDR isolate possesses three $\beta$-lactamases genes including a $b l a_{\text {OXA-51 }}$ variant $\left(b l a_{\mathrm{OXA}-317}\right), b l a_{\mathrm{OXA}-23}$, and $b l a_{\mathrm{ADC}-25}$ but not $b l a_{\mathrm{TEM}-1 \mathrm{D}}$.

\subsection{Mutation Analysis of Genes Conferring Colistin Resistance}

The PmrAB two-component system mediates colistin resistance in many Gramnegative bacteria including $A$. baumannii [51]. It regulates several genes encoding LPS modifying enzymes including $p m r C$, naxD, and ept $A$. Non-synonymous mutations in $p m-$ $r A B$ may dysregulate its downstream genes. Compared to the reference strain, the seven isolates harbored a number of non-synonymous mutations in the histidine kinase domain of $p m r B$ (Figure 1A). Three of the resulted amino acid substitutions (P233S, R263H, and Q270P) in PmrB are known to confer colistin resistance [17,52,53]. Two isolates, T1060578 and T1070213, harbored additional new substitutions outside the histidine kinase domain of PmrB, the effects of which are not known. No mutation was found in $p m r A$ in the seven isolates. New mutations in pmrC were found in two isolates, where T1060578 (ST136, Pasteur) harbored three non-synonymous mutations in $p m r C$ and one mutation in its promoter region. An L108S substitution in PmrC was found in T1070213. Pre-existing mutations in the population or mutations generated from antibiotic-induced stress responses are known to be selected under antibiotic treatments [54,55]. Indeed, our five patients, from whom the seven isolates were collected, had previously received colistin treatment. 
A

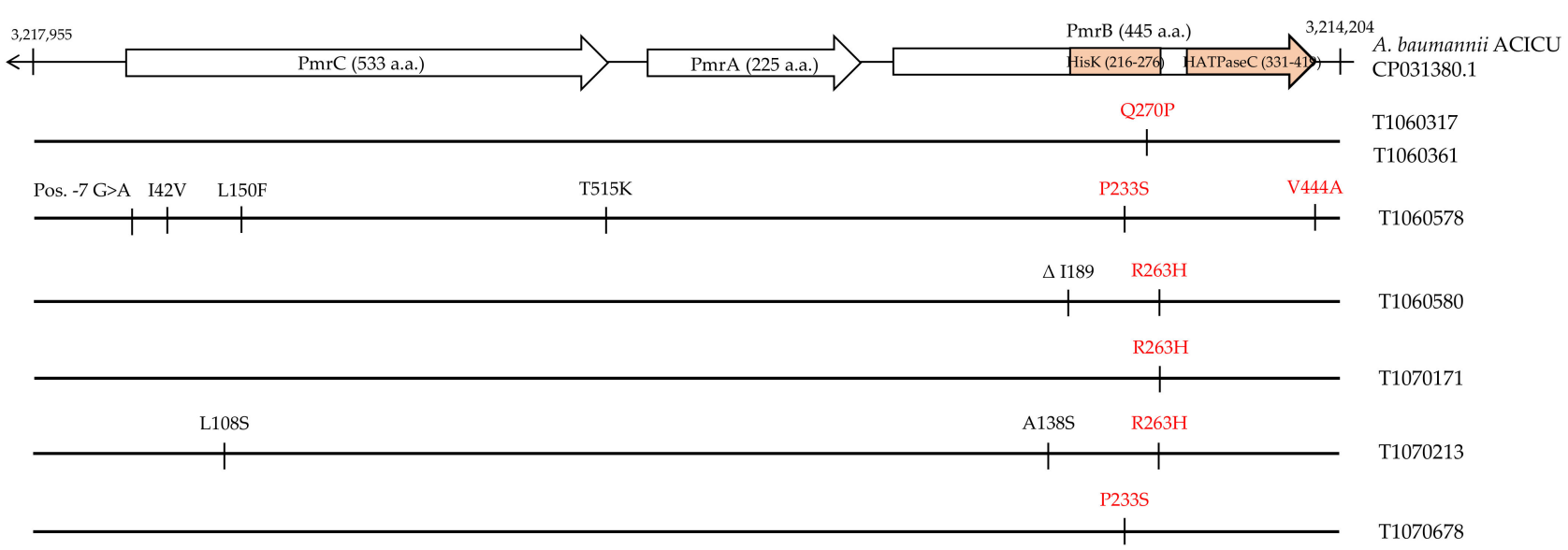

B

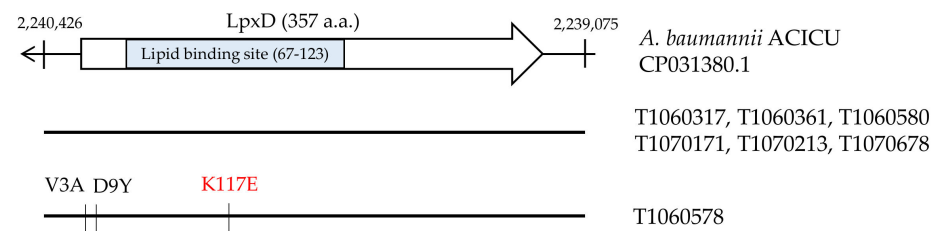

Figure 1. Amino acid substitutions in PmrC, PmrA, PmrB (A), and LpxD (B) in the CCR-AB isolates. The genetic map of the reference strain, ACICU, is displayed on the top with nucleotide numbers indicated. The open arrows depict the relevant genes with the names and size (in amino acid) shown. The functional domains in PmrB and LpxD are colored in orange and blue, respectively. Amino acid substitutions in the CCR-AB isolates are pictured below. Previously reported mutations are marked in red. Newly identified mutations are marked in black.

Mutations in LPS biosynthesis genes such as $\operatorname{lp} x A, \operatorname{lp} x C$, and $\operatorname{lp} x D$ may also result in colistin resistance $[22,23]$. Six of the seven isolates did not possess any mutation in these three genes, while T1060578 contained three non-synonymous mutations in $l p x D$. One of the substitutions (K117E) is at the lipid binding site, which has been associated with colistin resistance (Figure 1B). No mutation was found in other genes associated with colistin resistance including $p l d A$, pheS, vacj, lpsB, and miaA. These findings are consistent with previous reports showing that mutations in the histidine kinase domain of $\operatorname{pmr} B$ were mainly responsible for colistin resistance in clinical A. baumannii isolates [17-19].

\subsection{Effects of PmrB and LpxD Mutations}

Activation mutations in $p m r B$ (histidine kinase) result in constitutive expression of its downstream genes through the action of $p m r A$ (response regulator). Two of the $p m r B-$ regulated genes, $p m r C$ and ept $A$, encode phosphoethanolamine transferases, which add phosphoethanolamine ( $\mathrm{pEtN}$ ) to neutralize the negative charge on lipid A. Another pmrBregulated gene, $n a x D$, encodes an acetyl-galactosamine deacetylase, which modifies lipid A with galactosamine. Expression levels of these three genes in the seven isolates (Figure 2) were significantly increased compared to those in the reference culture. In each isolate, the expression of naxD was highest, followed by that of $\operatorname{pmrC}$ and eptA. T1070213, which was highly resistant to colistin, exhibited lower expression of these three genes than the other isolates with similar or lower colistin resistance. Comparison of T1070171 and T1070213 (from the same patient) showed an additional A138S substitution in PmrB in T1070213. It is possible that A138S attenuates the kinase activity of $\mathrm{PmrB}$, resulting in reduced expression of the downstream genes. 


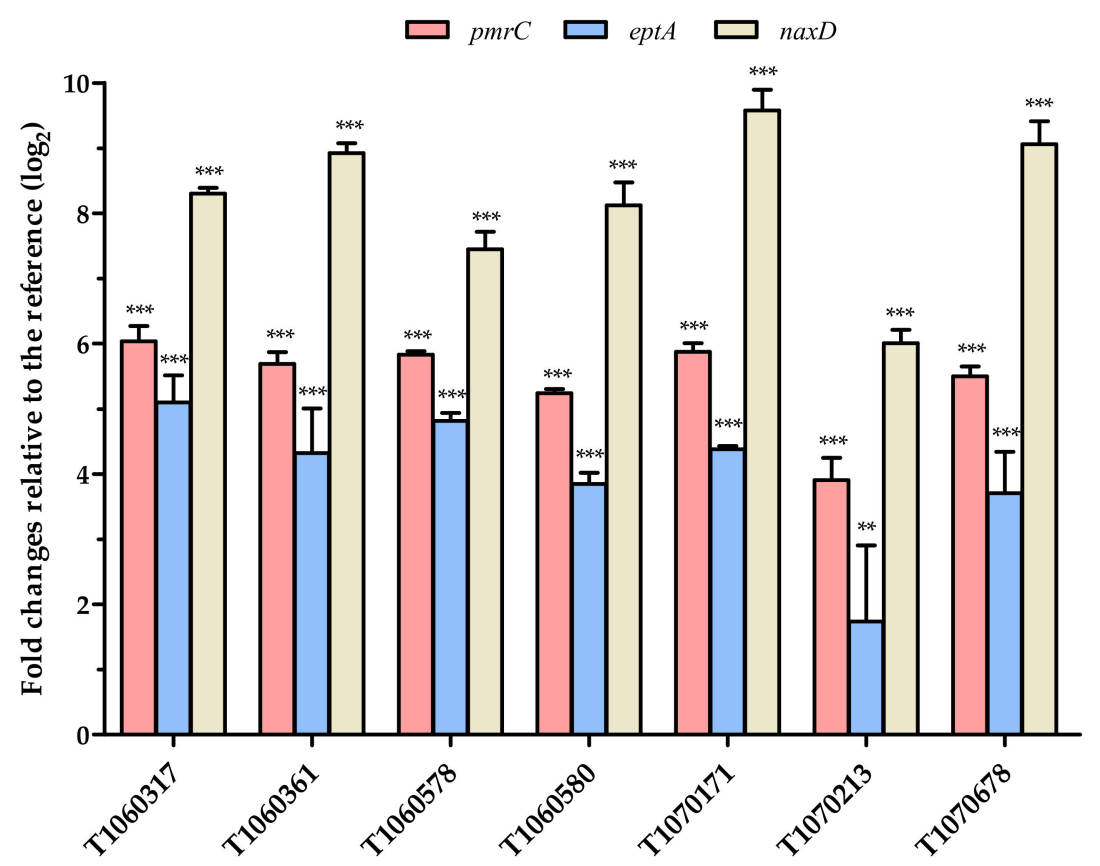

Figure 2. Gene expression levels of LPS modifying enzymes in the CCR-AB isolates. Expression of $\operatorname{pmrC}$, ept $A$, and naxD was compared to that of the reference strain ATCC 19606. The result was expressed in folds of changes in $\log _{2} \mathrm{scale} \mathrm{rpoB}$ was used as an internal reference for each isolate. The error bars indicate standard errors from three replicate determinations. Statistical analysis was conducted by one-way ANOVA with Dunnett's test for comparison of individual isolate and the reference. ${ }^{* *}, 0.001<p \leq 0.01 ;{ }^{* * *}, p \leq 0.001$.

Mutations in $l p x A, \operatorname{lp} x C$, or $\operatorname{lp} x D$ result in deficiency of LPS biosynthesis. The LPS profiling of the seven isolates was analyzed to evaluate the effect of mutations in LPS synthesis enzymes (Figure 3). Only T1060578 isolate with a K117E substitution in LpxD displayed a different LPS pattern compared to the reference and other CCR-AB isolates, all of which do not have an LpxD mutation. A single strong band near the bottom of the analyzed gel was observed in T1060578 but not the others.

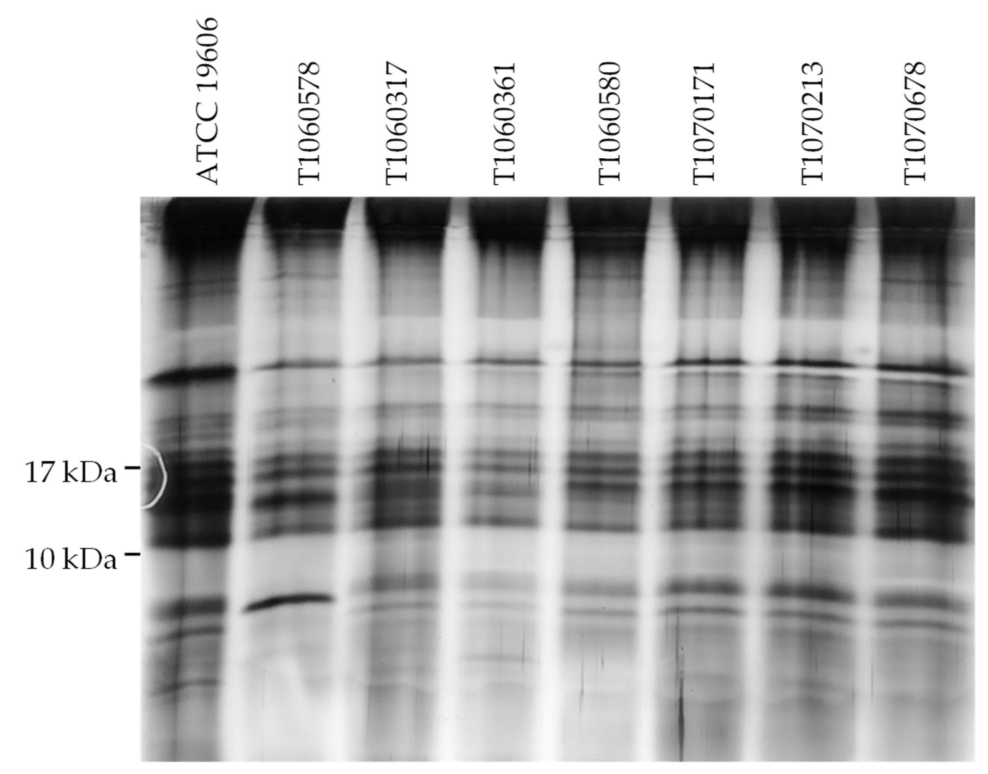

Figure 3. LPS profiles of the CCR-AB isolates. LPS extracted from each isolate was electrophoresed in $15 \%$ polyacrylamide gel and silver stained. The sizes of protein markers are shown to the left. The reference strain, ATCC 19606, represents a wild-type profile for comparison. 
These results indicate that colistin resistance in the CCR-AB isolates may involve either modifications of LPS or alterations in LPS biosynthesis. In particular, T1060578 appears to possess both mechanisms.

\subsection{Fitness, Biofilm Formation, and Heteroresistance to Colistin}

Alterations in LPS biosynthesis may affect bacterial growth and biofilm formation $[47,56]$. To understand the possible effects of activated $p m r B$ on the growth of the seven isolates, generation time was determined for each isolate. No significant difference in generation time was observed among them and the reference (Table S2), indicating no fitness cost was exerted on these isolates. Biofilm formation under aerated or non-aerated conditions was lower in the isolates than that in the reference (Figure 4): not detectable in the three GC2 isolates (T1060317, T1070213, and T1070678) and reduced formation in the remaining four. Interestingly, members of the two pairs of isolates (T1060317/T1060316, T1070171/T1070213) each from the same patient, differed significantly in biofilm production despite their highly similar genotypes.

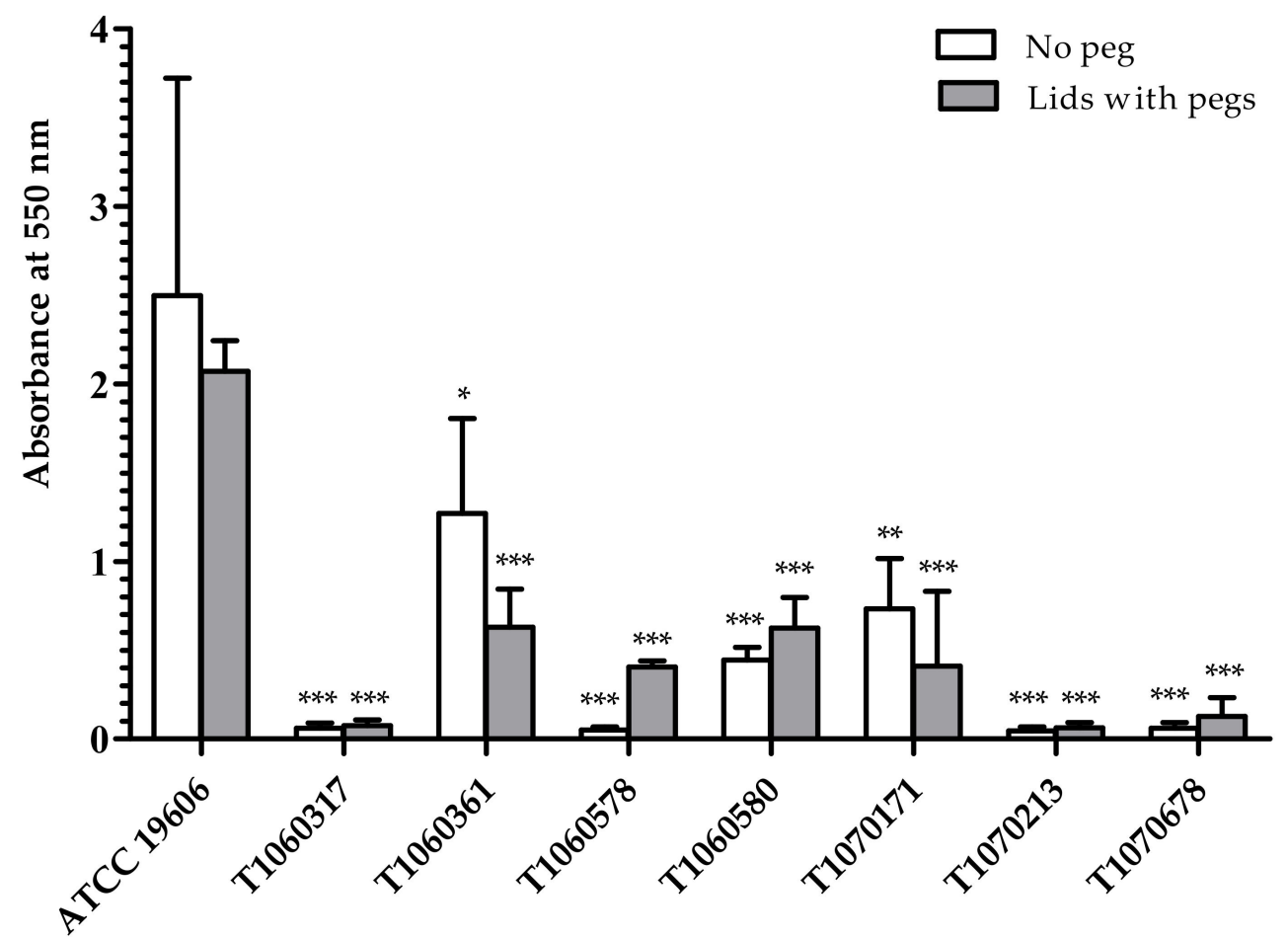

Figure 4. Biofilm formation abilities of the CCR-AB isolates. Individual bacterial suspension was cultured overnight in conventional 96-well plates ('No peg'; open bars) or in 96-wells with lid pegs (filled bar). Biofilms were measured by crystal violet staining. The ordinate represents measured absorbance at $550 \mathrm{~nm}$. The error bars indicate standard errors from three replicate determinations. Statistical analysis was calculated using one-way ANOVA with Dunnett's test for comparison to the reference, ATCC 19606. Numbers of asterisks indicate significant difference in different levels with $p$ $\left.\leq 0.001{ }^{* * *}\right), 0.001<p \leq 0.01\left(^{* *}\right)$, and $\left.0.01<p \leq 0.05{ }^{*}\right)$. 
Deficiency in biofilm formation has been reported in clinically isolated colistinresistant $A$. baumannii, which either contained mutations in $\operatorname{lp} x$ alone or mutations in pmrB and other biofilm-associated genes [57]. In silico analysis of biofilm-associated genes showed partial or complete deletion of $c s u$ fimbrial operon, a known biofilm-associated gene cluster in two of the three isolates (T1070213 and T1070678) deficient in biofilm formation (Table 3).

Table 3. In silico detection of virulence factors in the CCR-AB isolates.

\begin{tabular}{|c|c|c|c|c|c|c|c|c|c|}
\hline \multirow{2}{*}{ Category } & \multirow{2}{*}{ Gene } & \multirow{2}{*}{ Product } & \multicolumn{2}{|c|}{ ST2/ST544 } & \multicolumn{4}{|c|}{ ST2/ST208\&1806 } & \multirow{2}{*}{$\begin{array}{c}\text { ST136 } \\
\text { T1060578 }\end{array}$} \\
\hline & & & T1060317 & T1060361 & T1060580 & T1070171 & T1070213 & T1070678 & \\
\hline Adherence & отрA & $\begin{array}{l}\text { Outer membrane } \\
\text { protein OmpA }\end{array}$ & $100 / 100^{1}$ & $100 / 100$ & $100 / 100$ & $100 / 100$ & $100 / 100$ & $100 / 100$ & $98 / 100$ \\
\hline \multirow{2}{*}{ Quorum sensing } & $a b a R$ & $\begin{array}{l}\text { DNA-binding } \\
\text { HTH domain- } \\
\text { containing } \\
\text { protein }\end{array}$ & $98 / 100$ & $98 / 100$ & $98 / 100$ & $98 / 100$ & $98 / 100$ & $98 / 100$ & $98 / 100$ \\
\hline & $a b a I$ & $\begin{array}{c}\text { N-acyl-L- } \\
\text { homoserine } \\
\text { lactone synthetase }\end{array}$ & $98 / 100$ & $98 / 100$ & $98 / 100$ & $98 / 100$ & $98 / 100$ & $98 / 100$ & $98 / 100$ \\
\hline \multirow{3}{*}{ Enzymes } & $p l c D$ & Phospholipase & 99/99.8 & 99/99.8 & 98/99.8 & 99/99.8 & 99/99.8 & 99/99.8 & $95 / 99.8$ \\
\hline & $p l c$ & Phospholipase C & $100 / 100$ & $100 / 100$ & $100 / 100$ & $100 / 100$ & $100 / 100$ & $100 / 100$ & $97 / 100$ \\
\hline & $p l c$ & Phospholipase C & $99 / 100$ & $99 / 100$ & $99 / 100$ & $99 / 100$ & $99 / 100$ & $99 / 100$ & $99 / 100$ \\
\hline \multirow{6}{*}{$\begin{array}{l}\text { Biofilm -Csu } \\
\text { fimbriae }\end{array}$} & $c s u C$ & $\begin{array}{l}\text { Csu pilus } \\
\text { chaperone protein } \\
\text { CsuC }\end{array}$ & $100 / 100$ & $100 / 100$ & $100 / 100$ & $100 / 100$ & $100 / 100$ & Not found & $98 / 100$ \\
\hline & $\operatorname{csuA} / B$ & $\begin{array}{l}\text { Csu pilus major } \\
\text { pilin subunit } \\
\text { CsuA/B }\end{array}$ & $100 / 100$ & $100 / 100$ & $100 / 100$ & $100 / 100$ & $100 / 100$ & Not found & $99 / 100$ \\
\hline & $c s u B$ & $\begin{array}{l}\text { Csu pilus subunit } \\
\text { CsuB }\end{array}$ & $100 / 100$ & $100 / 100$ & $100 / 100$ & $100 / 100$ & $100 / 100$ & Not found & $98 / 100$ \\
\hline & $\operatorname{csu} \mathrm{D}$ & $\begin{array}{l}\text { Csu pilus subunit } \\
\text { CsuD }\end{array}$ & $99 / 100$ & $99 / 100$ & $99 / 100$ & $99 / 100$ & $100 / 20.8$ & Not found & $98 / 100$ \\
\hline & $\operatorname{csu} A$ & $\begin{array}{l}\text { Csu pilus usher } \\
\text { protein CsuA }\end{array}$ & $100 / 100$ & $100 / 100$ & $100 / 100$ & $100 / 100$ & $100 / 100$ & Not found & $98 / 100$ \\
\hline & $c s u E$ & $\begin{array}{l}\text { Csu pilus tip } \\
\text { adhesin CsuE }\end{array}$ & $99 / 100$ & $99 / 100$ & $99 / 100$ & 99/97.9 & Not found & Not found & $95 / 100$ \\
\hline \multirow{3}{*}{ Ade efflux pumps } & adeG & $\begin{array}{l}\text { Cation/multidrug } \\
\text { efflux pump } \\
\text { AdeG }\end{array}$ & $100 / 100$ & $100 / 100$ & $100 / 100$ & $100 / 100$ & $100 / 100$ & $100 / 100$ & $95 / 100$ \\
\hline & adeH & $\begin{array}{l}\text { Outer membrane } \\
\text { protein AdeH }\end{array}$ & $100 / 100$ & $100 / 100$ & $100 / 100$ & $100 / 100$ & $100 / 100$ & $100 / 100$ & $98 / 100$ \\
\hline & adeF & $\begin{array}{l}\text { Membrane-fusion } \\
\text { protein AdeF }\end{array}$ & $100 / 100$ & $100 / 100$ & $100 / 100$ & $100 / 100$ & $100 / 100$ & $100 / 100$ & $98 / 100$ \\
\hline \multirow{4}{*}{ Biofilm-PAGN ${ }^{2}$} & $p g a B$ & $\begin{array}{c}\text { PNAG } \\
\text { N-deacetylase } \\
\text { PgaB }\end{array}$ & $99 / 100$ & $99 / 100$ & $99 / 100$ & $99 / 100$ & $99 / 100$ & $99 / 100$ & $97 / 100$ \\
\hline & $p g a A$ & $\begin{array}{l}\text { PNAG export } \\
\text { porin PgaA }\end{array}$ & $98 / 99.8$ & $98 / 99.8$ & $98 / 99.8$ & $98 / 99.8$ & $98 / 99.8$ & $98 / 99.8$ & $97 / 100$ \\
\hline & $p g a C$ & PNAG synthase & $100 / 100$ & $100 / 100$ & $100 / 100$ & $100 / 100$ & $100 / 100$ & $100 / 100$ & $97 / 100$ \\
\hline & $p g a D$ & $\begin{array}{c}\text { PNAG } \\
\text { biosynthesis } \\
\text { protein PgaD }\end{array}$ & $100 / 100$ & $100 / 100$ & $100 / 100$ & $100 / 100$ & $100 / 100$ & $100 / 100$ & $97 / 100$ \\
\hline \multirow{2}{*}{ Regulation } & $b f m S$ & $\begin{array}{c}\text { Signal } \\
\text { transduction } \\
\text { histidine kinase } \\
\text { BfmS }\end{array}$ & $100 / 100$ & $100 / 100$ & $100 / 100$ & $100 / 100$ & $100 / 100$ & $100 / 100$ & $98 / 100$ \\
\hline & $b f m R$ & $\begin{array}{l}\text { Biofilm- } \\
\text { controlling } \\
\text { response } \\
\text { regulator BfmR }\end{array}$ & $100 / 100$ & $100 / 100$ & $100 / 100$ & $100 / 100$ & $100 / 100$ & $100 / 100$ & $99 / 100$ \\
\hline
\end{tabular}


Table 3. Cont.

\begin{tabular}{|c|c|c|c|c|c|c|c|c|c|}
\hline \multirow{2}{*}{ Category } & \multirow{2}{*}{ Gene } & \multirow{2}{*}{ Product } & \multicolumn{2}{|c|}{ ST2/ST544 } & \multicolumn{4}{|c|}{ ST2/ST208\&1806 } & \multirow{2}{*}{$\begin{array}{c}\text { ST136 } \\
\text { T1060578 }\end{array}$} \\
\hline & & & T1060317 & T1060361 & T1060580 & T1070171 & T1070213 & T1070678 & \\
\hline & bar $A$ & $\begin{array}{c}\text { Siderophore } \\
\text { efflux system of } \\
\text { the ABC } \\
\text { superfamily BarA }\end{array}$ & $100 / 100$ & $100 / 100$ & $100 / 100$ & $100 / 100$ & $100 / 100$ & Not found & $97 / 100$ \\
\hline & bar B & $\begin{array}{l}\text { Siderophore } \\
\text { efflux system of } \\
\text { the ABC } \\
\text { superfamily BarB }\end{array}$ & 99/99.9 & 99/99.9 & 99/99.9 & 99/99.9 & 99/99.9 & Not found & 97/99.9 \\
\hline & bas $A$ & $\begin{array}{l}\text { Acinetobactin } \\
\text { biosynthesis } \\
\text { protein BarA }\end{array}$ & $100 / 100$ & $100 / 100$ & $100 / 100$ & $100 / 100$ & $100 / 100$ & $100 / 100$ & $96 / 100$ \\
\hline & bas $B$ & $\begin{array}{l}\text { Non-ribosomal } \\
\text { peptide } \\
\text { synthetase BarB }\end{array}$ & $99 / 100$ & $99 / 100$ & $99 / 100$ & $99 / 100$ & $99 / 100$ & $99 / 100$ & $96 / 100$ \\
\hline & basC & $\begin{array}{l}\text { Acinetobactin } \\
\text { biosynthesis } \\
\text { protein BasC }\end{array}$ & $100 / 99.2$ & $100 / 99.2$ & $100 / 99.2$ & $100 / 99.2$ & $100 / 99.2$ & $100 / 99.2$ & $97 / 99.2$ \\
\hline & bas $D$ & $\begin{array}{l}\text { Acinetobactin } \\
\text { biosynthesis } \\
\text { protein BasD }\end{array}$ & $99 / 100$ & $99 / 100$ & $99 / 100$ & $99 / 100$ & $99 / 100$ & $99 / 100$ & $96 / 100$ \\
\hline & basF & $\begin{array}{l}\text { Aryl carrier } \\
\text { protein BasF }\end{array}$ & $100 / 100$ & $100 / 100$ & $100 / 100$ & $100 / 100$ & $100 / 100$ & $100 / 100$ & $97 / 100$ \\
\hline & bas $G$ & $\begin{array}{l}\text { Acinetobactin } \\
\text { biosynthesis } \\
\text { protein BasF }\end{array}$ & $100 / 100$ & $100 / 100$ & $100 / 100$ & $100 / 100$ & $100 / 100$ & Not found & $97 / 100$ \\
\hline & $b a s H$ & $\begin{array}{c}\text { Non-ribosomal } \\
\text { peptide } \\
\text { biosynthesis } \\
\text { thioesterase BasH }\end{array}$ & $100 / 100$ & $100 / 100$ & $100 / 100$ & $100 / 100$ & $100 / 100$ & Not found & $96 / 100$ \\
\hline \multirow[t]{9}{*}{ Iron uptake } & basI & $\begin{array}{l}\text { Acinetobactin } \\
\text { biosynthesis } \\
\text { protein BasI }\end{array}$ & $97 / 98.8$ & $97 / 98.8$ & $97 / 98.8$ & $97 / 98.8$ & $97 / 98.8$ & Not found & $93 / 98.8$ \\
\hline & basJ & $\begin{array}{l}\text { Acinetobactin } \\
\text { biosynthesis } \\
\text { protein BasJ }\end{array}$ & $98 / 100$ & $98 / 100$ & $98 / 100$ & $98 / 100$ & $98 / 100$ & Not found & $98 / 100$ \\
\hline & entE & $\begin{array}{l}\text { Non-ribosomal } \\
\text { peptide } \\
\text { synthetase EntE }\end{array}$ & $100 / 100$ & $100 / 100$ & $100 / 100$ & $100 / 100$ & $100 / 100$ & $100 / 100$ & $96 / 100$ \\
\hline & bauA & $\begin{array}{l}\text { TonB-dependent } \\
\text { siderophore } \\
\text { receptor BauA }\end{array}$ & $99 / 100$ & $99 / 100$ & $99 / 100$ & $99 / 100$ & $99 / 100$ & $99 / 100$ & $99 / 100$ \\
\hline & ваив & $\begin{array}{c}\text { Ferric siderophore } \\
\text { ABC transporter, } \\
\text { periplasmic } \\
\text { siderophore- } \\
\text { binding protein } \\
\text { BauB }\end{array}$ & $100 / 100$ & $100 / 100$ & $100 / 100$ & $100 / 100$ & $100 / 100$ & $100 / 100$ & $97 / 100$ \\
\hline & bauc & $\begin{array}{l}\text { Ferric siderophore } \\
\text { ABC transporter, } \\
\text { permease protein } \\
\text { BauC }\end{array}$ & $98 / 100$ & $98 / 100$ & $98 / 100$ & $98 / 100$ & $98 / 100$ & $98 / 100$ & $95 / 83.1$ \\
\hline & bauD & $\begin{array}{c}\text { Ferric siderophore } \\
\text { ABC transporter, } \\
\text { permease protein } \\
\text { BauD }\end{array}$ & $99 / 100$ & $99 / 100$ & $99 / 100$ & $99 / 100$ & $99 / 100$ & $99 / 100$ & 96/99.9 \\
\hline & bauE & $\begin{array}{l}\text { Ferric siderophore } \\
\text { ABC transporter, } \\
\text { ATP-binding } \\
\text { protein BauE }\end{array}$ & $100 / 100$ & $100 / 100$ & $100 / 100$ & $100 / 100$ & $100 / 100$ & $100 / 100$ & $99 / 100$ \\
\hline & bauF & $\begin{array}{l}\text { Siderophore- } \\
\text { interacting } \\
\text { protein }\end{array}$ & $100 / 100$ & $100 / 100$ & $100 / 100$ & $100 / 100$ & $100 / 100$ & $100 / 100$ & $97 / 100$ \\
\hline
\end{tabular}

${ }^{1}$ Values represent identities and coverages of nucleotide sequence comparison between our isolates and the reference A. baumannii ACICU. The gray color indicates $100 \%$ identity to the reference in both identity and coverage. ${ }^{2}$ PNAG: Poly-beta-1,6-N-acetyl-D-glucosamine.

A 33\% prevalence of colistin heteroresistance in Acinetobacter spp. based on a metaanalysis has been reported [58]. In the seven CCR-AB isolates, six displayed stable resistance to colistin with a higher than $40 \%$ survival rate at the highest colistin concentration tested $(64 \mathrm{mg} / \mathrm{L})$. The other isolate, T1070678, displayed heteroresistance with $3.8 \times 10^{-2}$ survival at $16 \mathrm{mg} / \mathrm{L}$ of colistin (Figure 5). T1070678 contains a P233S substitution in PmrB, which is known to be associated with stable resistance [59]. No reported mutations in pmrA or pmrB are known to be involved in heteroresistance. It is possible that colistin heteroresistance in T1070678 may be attributed to elevated efflux pumps, as has been previously reported [60]. 


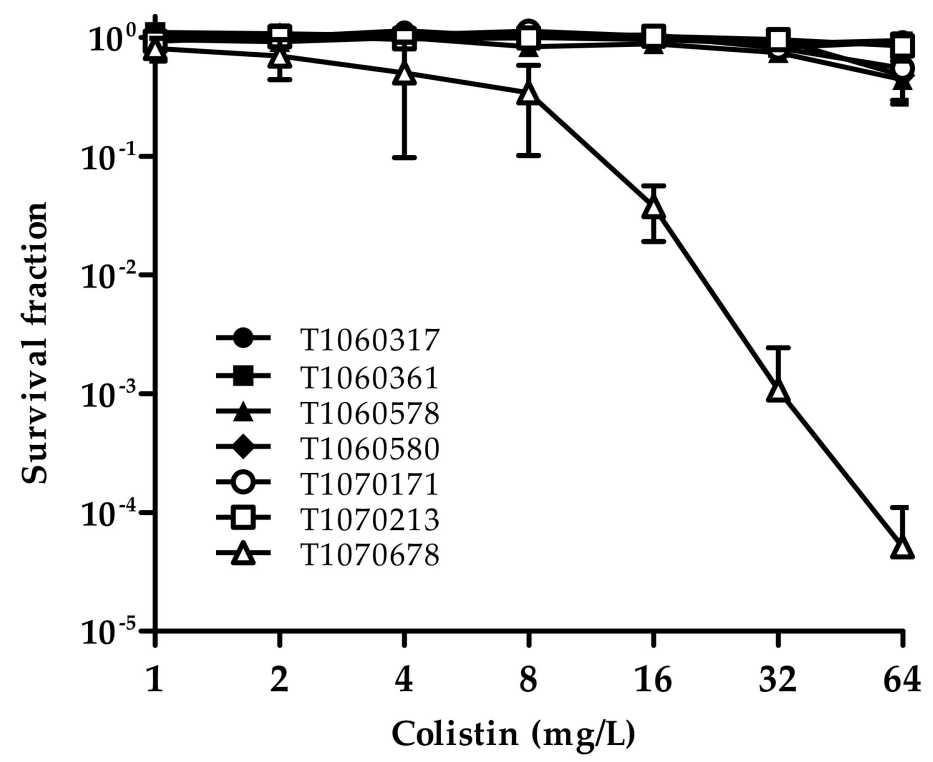

Figure 5. Population analysis profiles of the CCR-AB isolates. An overnight culture of each isolate was serial diluted 10-fold. The diluted bacterial suspension was plated onto LB agar, with colistin concentration ranging from 0 to $64 \mathrm{mg} / \mathrm{L}$. CFU was counted in each agar. The survival fraction in each colistin concentration was calculated by comparing it to CFU on colistin-free medium. The results present the average of three replicates with standard errors depicted by the error bars.

\subsection{Virulence to Wax Moth}

Colistin resistance in $A$. baumannii isolates has been shown to be associated with virulence reduction $[30,61]$. Virulence of the CCR-AB isolates was analyzed using the wax moth infection model. Most of our CCR-AB isolates were more virulent to different degrees than the reference strain A. baumannii AYE (Figure 6). Three (T1060580, T1070171, and T1070213) out of four isolates classified as ST208 and ST1806 (Oxford) killed more than $60 \%$ of larvae $72 \mathrm{~h}$ post-injection. The most virulent isolate, T1070213, killed more than $80 \%$ of larvae $48 \mathrm{~h}$ post-injection. Such virulence of T1070213 is comparable to that of a known virulent strain AB5057 using the same test model [62]. Interestingly, T1070213, isolated from the same patient as T1070171 but two weeks later, exhibited significantly higher virulence than the latter. The high virulence of T1070213 is of interest. While hypervirulent CRAB isolates outside of ST208 have been described [63], no hypervirulent ST208 isolate has been reported. It is possible that the high virulence of T1070213 is due to higher resistance to the complement system in the innate immunity in wax moth. 

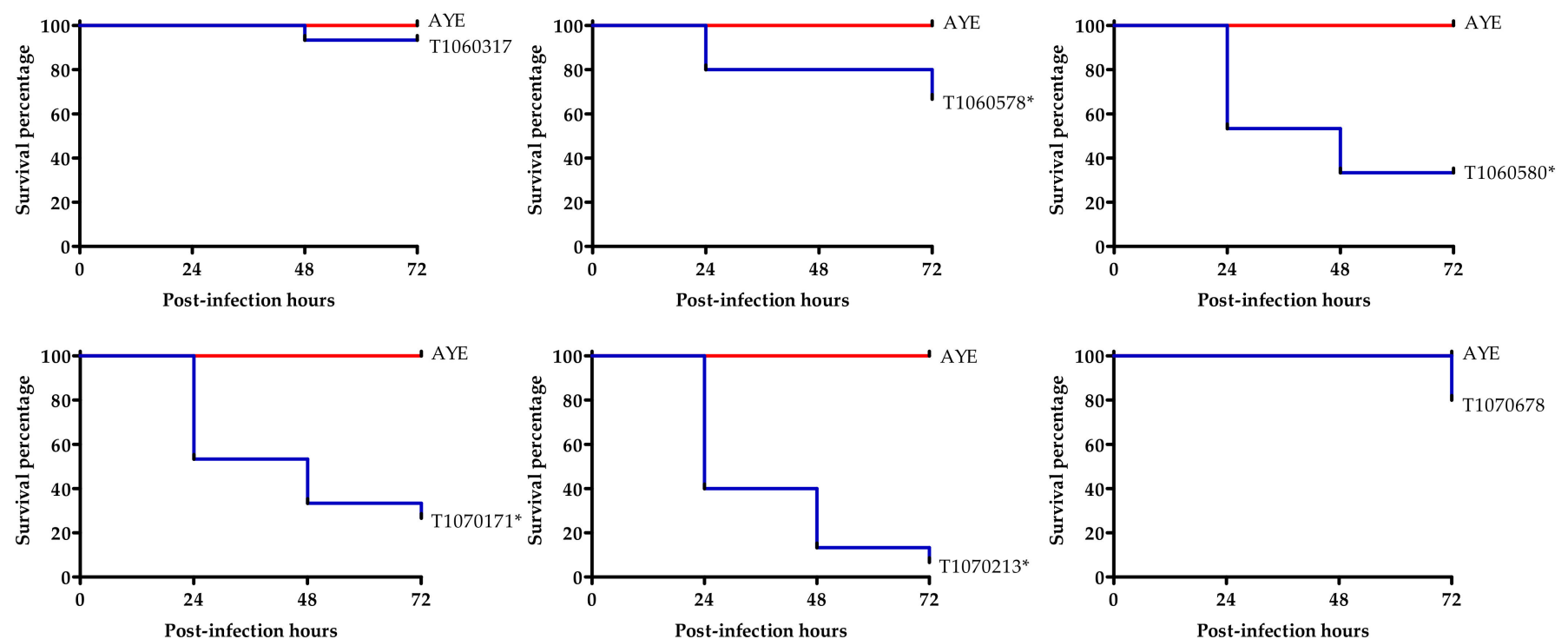

Figure 6. Survival curve of wax moth larvae after injection of the CCR-AB isolates. Fifteen larvae at the late larva stage were injected with $10^{5} \mathrm{CFU}$ of each isolate culture. Survival of the injected larvae after 24, 48, and $72 \mathrm{~h}$ were scored. The survival curves were plotted using Kaplan-Meier analysis. PBS solution injection (as a negative control) exhibited no lethality during the observation period. A. baumannii AYE was used as a reference for comparison. Representative results from three independent replicates are shown. The asterisks $\left.{ }^{*}\right)$ indicate the significant difference $(p<0.01)$ between the reference and tested isolate.

\subsection{In Silico Analysis of Virulence Factors}

In silico analysis of 39 known virulence factors from the draft genomes shows high similarities (Table 3). Identities and coverage in these virulence factors were nearly the same among the GC2 isolates, although the ST208 and ST1806 (Oxford) isolates were more virulent to moth larvae than the ST544 (Oxford) isolates. It implies that other factors contribute to the higher virulence of the ST208 and ST1806 (Oxford) isolates. One isolate (T1070678) in ST208 and ST1806 (Oxford) has lost the csu fimbriae operon and part of the acinetobactin biosynthesis gene cluster and exhibited the avirulent phenotype, suggesting that the missing genes are required for virulence. Interestingly, T1070213, despite lacking complete $c s u$ operon (encoding a virulent factor), is more virulent than its paired isolate, T1070171. We suspect that T1070213 may contain one or more novel virulence factors.

\subsection{Potentially Alternative Therapies against MDR Bacteria}

The need to discover new approaches against MDR bacteria is urgent. Combination therapies with compounds to increase membrane permeability or to reduce efflux pump activity have been proposed [64]. The use of efflux pump inhibitors as antibiotic adjuvants may elevate the efficacy of antibiotics. Many natural and synthetic compounds acting as efflux pump inhibitors have been found to be effective against Gram-positive and Gramnegative MDR bacteria $[65,66]$. Some plant products such as essential oils have shown broad-spectrum activities against bacteria and fungi $[67,68]$. In particular, oregano essential oil has been shown to inhibit the growth of MDR A. baumannii and function synergistically with polymyxin B [69]. Another essential oil from Zingiber cassumunar Roxb exhibited antibacterial activities and enhancing effects for several classes of antibiotics against $A$. baumannii, including XDR isolates [70]. Alternative therapies such as these may aid our continuing fight against MDR bacteria.

\section{Conclusions}

In this study, we collected seven CCR-AB isolates from a teaching hospital in Taiwan and performed genomic epidemiology to uncover their molecular features and resistome 
profiles. Most of the isolates were endemic GC2 clones and acquired multiple antimicrobial resistance determinants. Carbapenemase OXA-23 is responsible for carbapenem resistance, while colistin resistance was mediated through $p m r B$ mutations that alter lipid A and/or LPS in our isolates. Colistin heteroresistance was found in one isolate. Different biofilm formation abilities and virulence were found among GC2 isolates and between paired isolates from the same patients, implying other genetic traits may be involved in these phenomena.

Supplementary Materials: The following are available online at https://www.mdpi.com/article/10 .3390 / microorganisms9061295/s1. Table S1. Oligonucleotide sequences used in this study. Table S2. Generation time of colistin- and carbapenem-resistant Acinetobacter baumannii isolates.

Author Contributions: Conceptualization: N.A.I., Y.-J.L., and T.-W.H.; data curation: S.-C.K., N.A.I., and T.-W.H.; methodology: N.A.I., I.-H.L., and T.-W.H.; writing-original draft: N.A.I. and T.-W.H.; writing-review and editing: Y.-J.L., S.-C.K., and T.-W.H. All authors have read and agreed to the published version of the manuscript.

Funding: This research was funded by the National Health Research Institutes (Grant Numbers MG-108-GP-07 and MG-109-GP-01) and the Ministry of Science and Technology (Grant Number MOST 109-2320-B-038-051).

Institutional Review Board Statement: The study was conducted according to the guidelines of the Declaration of Helsinki and approved by Taipei Medical University_Joint Institutional Review Board (N201609001, date of approval: 2016/09/03).

Informed Consent Statement: Patient consent was waived due to the retrospective study with anonymous clinical data.

Data Availability Statement: Data are provided in the article and Supplementary Materials.

Acknowledgments: We thank College of Medicine in Taipei Medical University for supporting the long-term collection of antibiotic-resistant bacteria and the staff of Taipei Medical University Hospital for assistance in bacterial collection. We acknowledge the Genomics Center for Clinical and Biotechnological Applications of National Core Facility for Biopharmaceuticals, Taiwan (MOST 109-2740-B-010-002) for sequencing service. We thank Carton W. Chen for critical reading of the manuscript.

Conflicts of Interest: The authors declare no conflict of interest.

\section{References}

1. O'Neill, J. Antimicrobial Resistance: Tackling a crisis for the health and wealth of nations. In Review on Antimicrobial Resistance; Wellcome Trust: London, UK, 2014; pp. 1-16. Available online: http://www.jpiamr.eu/wp-content/uploads/2014/12/AMRReview-Paper-Tackling-a-crisis-for-the-health-and-wealth-of-nations_1-2.pdf (accessed on 31 March 2021).

2. World Health Organization. Global priority list of antibiotic-resistant bacteria-To guide research, discovery, and development of new antibiotics. 2017. Available online: https:/ / www.who.int/medicines/publications/global-priority-list-antibiotic-resistantbacteria/en/ (accessed on 31 March 2021).

3. Kanj, S.S.; Kanafani, Z.A. Current concepts in antimicrobial therapy against resistant Gram-negative organisms: extendedspectrum $\beta$-lactamase-producing Enterobacteriaceae, carbapenem-resistant Enterobacteriaceae, and multidrug-resistant $P_{s e u}$ domonas aeruginosa. Mayo Clin. Proc. 2011, 86, 250-259. [CrossRef] [PubMed]

4. Tacconelli, E.; Carrara, E.; Savoldi, A.; Harbarth, S.; Mendelson, M.; Monnet, D.L.; Pulcini, C.; Kahlmeter, G.; Kluytmans, J.; Carmeli, Y.; et al. Discovery, research, and development of new antibiotics: the WHO priority list of antibiotic-resistant bacteria and tuberculosis. Lancet Infect. Dis. 2018, 18, 318-327. [CrossRef]

5. Sievert, D.M.; Ricks, P.; Edwards, J.R.; Schneider, A.; Patel, J.; Srinivasan, A.; Kallen, A.; Limbago, B.; Fridkin, S. National Healthcare Safety Network, T., et al. Antimicrobial-resistant pathogens associated with healthcare-associated infections: summary of data reported to the National Healthcare Safety Network at the Centers for Disease Control and Prevention, 2009-2010. Infect. Control. Hosp. Epidemiol. 2013, 34, 1-14. [CrossRef] [PubMed]

6. Dijkshoorn, L.; Nemec, A.; Seifert, H. An increasing threat in hospitals: multidrug-resistant Acinetobacter baumannii. Nat. Rev. Microbiol. 2007, 5, 939-951. [CrossRef]

7. Kuo, S.C.; Chang, S.C.; Wang, H.Y.; Lai, J.F.; Chen, P.C.; Shiau, Y.R.; Huang, I.W.; Lauderdale, T.L. TSAR Hospitals. Emergence of extensively drug-resistant Acinetobacter baumannii complex over 10 years: nationwide data from the Taiwan Surveillance of Antimicrobial Resistance (TSAR) program. BMC Infect. Dis. 2012, 12, 200. [CrossRef] 
8. Taiwan Centers for Disease Control. Annual report of nosocomial infections surveillance system (2016). Taiwan Nosocomial Infections. Surveillance system. Available online: https:/ / www.cdc.gov.tw/En/Category/Page/J63NmsvevBg2u3I2qYBenw (accessed on 31 March 2021).

9. Centers for Disease Control and Prevention. Antibiotic resistance threats in the United States, 2019. U.S. Department of Health and Human Services, Centers for Disease Control and Prevention. 2019. Available online: https://www.cdc.gov/DrugResistance/ Biggest-Threats.html (accessed on 31 March 2021).

10. Bakour, S.; Olaitan, A.O.; Ammari, H.; Touati, A.; Saoudi, S.; Saoudi, K.; Rolain, J.M. Emergence of colistin- and carbapenemresistant Acinetobacter baumannii ST2 clinical isolate in Algeria: first case report. Microb. Drug Resist. 2015, 21, 279-285. [CrossRef]

11. Oikonomou, O.; Sarrou, S.; Papagiannitsis, C.C.; Georgiadou, S.; Mantzarlis, K.; Zakynthinos, E.; Dalekos, G.N.; Petinaki, E. Rapid dissemination of colistin and carbapenem resistant Acinetobacter baumannii in Central Greece: mechanisms of resistance, molecular identification and epidemiological data. BMC Infect. Dis. 2015, 15, 559. [CrossRef]

12. Qureshi, Z.A.; Hittle, L.E.; O’Hara, J.A.; Rivera, J.I.; Syed, A.; Shields, R.K.; Pasculle, A.W.; Ernst, R.K.; Doi, Y. Colistin-resistant Acinetobacter baumannii: beyond carbapenem resistance. Clin. Infect. Dis. 2015, 60, 1295-1303. [CrossRef]

13. Li, J.; Nation, R.L.; Turnidge, J.D.; Milne, R.W.; Coulthard, K.; Rayner, C.R.; Paterson, D.L. Colistin: the re-emerging antibiotic for multidrug-resistant Gram-negative bacterial infections. Lancet Infect. Dis. 2006, 6, 589-601. [CrossRef]

14. Hameed, F.; Khan, M.A.; Muhammad, H.; Sarwar, T.; Bilal, H.; Rehman, T.U. Plasmid-mediated mcr-1 gene in Acinetobacter baumannii and Pseudomonas aeruginosa: first report from Pakistan. Rev. Soc. Bras. Med. Trop. 2019, 52, e20190237. [CrossRef] [PubMed]

15. Ma, F.; Shen, C.; Zheng, X.; Liu, Y.; Chen, H.; Zhong, L.; Liang, Y.; Liao, K.; Xia, Y.; Tian, G.B.; et al. Identification of a novel plasmid carrying mcr-4.3 in an Acinetobacter baumannii strain in China. Antimicrob. Agents Chemother. 2019, 63. [CrossRef] [PubMed]

16. Martins-Sorenson, N.; Snesrud, E.; Xavier, D.E.; Cacci, L.C.; Iavarone, A.T.; McGann, P.; Riley, L.W.; Moreira, B.M. A novel plasmid-encoded mcr-4.3 gene in a colistin-resistant Acinetobacter baumannii clinical strain. J. Antimicrob. Chemother. 2020, 75, 60-64. [CrossRef] [PubMed]

17. Arroyo, L.A.; Herrera, C.M.; Fernandez, L.; Hankins, J.V.; Trent, M.S.; Hancock, R.E. The pmrCAB operon mediates polymyxin resistance in Acinetobacter baumannii ATCC 17978 and clinical isolates through phosphoethanolamine modification of lipid A. Antimicrob. Agents Chemother. 2011, 55, 3743-3751. [CrossRef]

18. Beceiro, A.; Llobet, E.; Aranda, J.; Bengoechea, J.A.; Doumith, M.; Hornsey, M.; Dhanji, H.; Chart, H.; Bou, G.; Livermore, D.M.; et al. Phosphoethanolamine modification of lipid A in colistin-resistant variants of Acinetobacter baumannii mediated by the $p m r A B$ two-component regulatory system. Antimicrob. Agents Chemother. 2011, 55, 3370-3379. [CrossRef] [PubMed]

19. Lesho, E.; Yoon, E.J.; McGann, P.; Snesrud, E.; Kwak, Y.; Milillo, M.; Onmus-Leone, F.; Preston, L.; St Clair, K.; Nikolich, M.; et al. Emergence of colistin-resistance in extremely drug-resistant Acinetobacter baumannii containing a novel pmrCAB operon during colistin therapy of wound infections. J. Infect. Dis. 2013, 208, 1142-1151. [CrossRef]

20. De Silva, P.M.; Kumar, A. Signal transduction proteins in Acinetobacter baumannii: role in antibiotic resistance, virulence, and potential as drug targets. Front. Microbiol. 2019, 10, 49. [CrossRef] [PubMed]

21. Chin, C.Y.; Gregg, K.A.; Napier, B.A.; Ernst, R.K.; Weiss, D.S. A PmrB-regulated deacetylase required for lipid A modification and polymyxin resistance in Acinetobacter baumannii. Antimicrob. Agents Chemother. 2015, 59, 7911-7914. [CrossRef]

22. Moffatt, J.H.; Harper, M.; Harrison, P.; Hale, J.D.; Vinogradov, E.; Seemann, T.; Henry, R.; Crane, B.; St Michael, F.; Cox, A.D.; et al. Colistin resistance in Acinetobacter baumannii is mediated by complete loss of lipopolysaccharide production. Antimicrob. Agents Chemother. 2010, 54, 4971-4977. [CrossRef]

23. Moffatt, J.H.; Harper, M.; Adler, B.; Nation, R.L.; Li, J.; Boyce, J.D. Insertion sequence ISAba11 is involved in colistin resistance and loss of lipopolysaccharide in Acinetobacter baumannii. Antimicrob. Agents Chemother. 2011, 55, 3022-3024. [CrossRef]

24. Hood, M.I.; Becker, K.W.; Roux, C.M.; Dunman, P.M.; Skaar, E.P. Genetic determinants of intrinsic colistin tolerance in Acinetobacter baumannii. Infect. Immun. 2013, 81, 542-551. [CrossRef]

25. Bojkovic, J.; Richie, D.L.; Six, D.A.; Rath, C.M.; Sawyer, W.S.; Hu, Q.; Dean, C.R. Characterization of an Acinetobacter baumannii lptD deletion strain: permeability defects and response to inhibition of lipopolysaccharide and fatty acid biosynthesis. J. Bacteriol. 2015, 198, 731-741. [CrossRef]

26. Thi Khanh Nhu, N.; Riordan, D.W.; Do Hoang Nhu, T.; Thanh, D.P.; Thwaites, G.; Huong Lan, N.P.; Wren, B.W.; Baker, S.; Stabler, R.A. The induction and identification of novel colistin resistance mutations in Acinetobacter baumannii and their implications. Sci. Rep. 2016, 6, 28291. [CrossRef]

27. Lin, M.F.; Lin, Y.Y.; Lan, C.Y. Contribution of EmrAB efflux pumps to colistin resistance in Acinetobacter baumannii. J. Microbiol. 2017, 55, 130-136. [CrossRef]

28. Lopez-Rojas, R.; Dominguez-Herrera, J.; McConnell, M.J.; Docobo-Perez, F.; Smani, Y.; Fernandez-Reyes, M.; Rivas, L.; Pachon, J. Impaired virulence and in vivo fitness of colistin-resistant Acinetobacter baumannii. J. Infect. Dis. 2011, 203, 545-548. [CrossRef] [PubMed]

29. Rolain, J.M.; Roch, A.; Castanier, M.; Papazian, L.; Raoult, D. Acinetobacter baumannii resistant to colistin with impaired virulence: a case report from France. J. Infect. Dis. 2011, 204, 1146-1147. [CrossRef] [PubMed] 
30. Beceiro, A.; Moreno, A.; Fernandez, N.; Vallejo, J.A.; Aranda, J.; Adler, B.; Harper, M.; Boyce, J.D.; Bou, G. Biological cost of different mechanisms of colistin resistance and their impact on virulence in Acinetobacter baumannii. Antimicrob. Agents Chemother. 2014, 58, 518-526. [CrossRef]

31. Carretero-Ledesma, M.; Garcia-Quintanilla, M.; Martin-Pena, R.; Pulido, M.R.; Pachon, J.; McConnell, M.J. Phenotypic changes associated with colistin resistance due to lipopolysaccharide loss in Acinetobacter baumannii. Virulence 2018, 9, 930-942. [CrossRef]

32. Lopez-Rojas, R.; Jimenez-Mejias, M.E.; Lepe, J.A.; Pachon, J. Acinetobacter baumannii resistant to colistin alters its antibiotic resistance profile: a case report from Spain. J. Infect. Dis. 2011, 204, 1147-1148. [CrossRef]

33. Durante-Mangoni, E.; Del Franco, M.; Andini, R.; Bernardo, M.; Giannouli, M.; Zarrilli, R. Emergence of colistin resistance without loss of fitness and virulence after prolonged colistin administration in a patient with extensively drug-resistant Acinetobacter baumannii. Diagn. Microbiol. Infect. Dis. 2015, 82, 222-226. [CrossRef] [PubMed]

34. Pormohammad, A.; Mehdinejadiani, K.; Gholizadeh, P.; Nasiri, M.J.; Mohtavinejad, N.; Dadashi, M.; Karimaei, S.; Safari, H.; Azimi, T. Global prevalence of colistin resistance in clinical isolates of Acinetobacter baumannii: A systematic review and metaanalysis. Microb. Pathog. 2020, 139, 103887. [CrossRef]

35. Jean, S.S.; Hsueh, P.R.; Lee, W.S.; Chang, H.T.; Chou, M.Y.; Chen, I.S.; Wang, J.H.; Lin, C.F.; Shyr, J.M.; Ko, W.C.; et al. Nationwide surveillance of antimicrobial resistance among non-fermentative Gram-negative bacteria in Intensive Care Units in Taiwan: SMART programme data 2005. Int. J. Antimicrob. Agents 2009, 33, 266-271. [CrossRef] [PubMed]

36. Lai, C.C.; Chen, Y.S.; Lee, N.Y.; Tang, H.J.; Lee, S.S.; Lin, C.F.; Lu, P.L.; Wu, J.J.; Ko, W.C.; Lee, W.S.; et al. Susceptibility rates of clinically important bacteria collected from intensive care units against colistin, carbapenems, and other comparative agents: results from Surveillance of Multicenter Antimicrobial Resistance in Taiwan (SMART). Infect. Drug Resist. 2019, 12, 627-640. [CrossRef]

37. Chang, K.C.; Lin, M.F.; Lin, N.T.; Wu, W.J.; Kuo, H.Y.; Lin, T.Y.; Yang, T.L.; Chen, Y.C.; Liou, M.L. Clonal spread of multidrugresistant Acinetobacter baumannii in eastern Taiwan. J. Microbiol. Immunol. Infect. 2012, 45, 37-42. [CrossRef]

38. CLSI. Performance Standards for Antimicrobial Susceptibility Testing, 28 ed.; Clinical and Laboratory Standards Institute: Wayne, Pennsylvania, USA, 2018.

39. Higgins, P.G.; Lehmann, M.; Wisplinghoff, H.; Seifert, H. gyrB multiplex PCR to differentiate between Acinetobacter calcoaceticus and Acinetobacter genomic species 3. J. Clin. Microbiol. 2010, 48, 4592-4594. [CrossRef] [PubMed]

40. Diancourt, L.; Passet, V.; Nemec, A.; Dijkshoorn, L.; Brisse, S. The population structure of Acinetobacter baumannii: expanding multiresistant clones from an ancestral susceptible genetic pool. PLoS One 2010, 5, e10034. [CrossRef]

41. Bartual, S.G.; Seifert, H.; Hippler, C.; Luzon, M.A.; Wisplinghoff, H.; Rodriguez-Valera, F. Development of a multilocus sequence typing scheme for characterization of clinical isolates of Acinetobacter baumannii. J. Clin. Microbiol. 2005, 43, 4382-4390. [CrossRef]

42. Wyres, K.L.; Cahill, S.M.; Holt, K.E.; Hall, R.M.; Kenyon, J.J. Identification of Acinetobacter baumannii loci for capsular polysaccharide (KL) and lipooligosaccharide outer core (OCL) synthesis in genome assemblies using curated reference databases compatible with Kaptive. Microb. Genom. 2020, 6. [CrossRef]

43. Larsen, M.V.; Cosentino, S.; Rasmussen, S.; Friis, C.; Hasman, H.; Marvig, R.L.; Jelsbak, L.; Sicheritz-Ponten, T.; Ussery, D.W.; Aarestrup, F.M.; et al. Multilocus sequence typing of total-genome-sequenced bacteria. J. Clin. Microbiol. 2012, 50, 1355-1361. [CrossRef] [PubMed]

44. Liu, B.; Zheng, D.; Jin, Q.; Chen, L.; Yang, J. VFDB 2019: a comparative pathogenomic platform with an interactive web interface. Nucleic Acids Res. 2019, 47, D687-D692. [CrossRef] [PubMed]

45. Schmittgen, T.D.; Livak, K.J. Analyzing real-time PCR data by the comparative C(T) method. Nat. Protoc. 2008, 3, 1101-1108. [CrossRef]

46. Hall, B.G.; Acar, H.; Nandipati, A.; Barlow, M. Growth rates made easy. Mol. Biol. Evol. 2014, 31, 232-238. [CrossRef] [PubMed]

47. Dafopoulou, K.; Xavier, B.B.; Hotterbeekx, A.; Janssens, L.; Lammens, C.; De, E.; Goossens, H.; Tsakris, A.; Malhotra-Kumar, S.; Pournaras, S. Colistin-resistant Acinetobacter baumannii clinical strains with deficient biofilm formation. Antimicrob. Agents Chemother. 2015, 60, 1892-1895. [CrossRef]

48. Sherman, E.X.; Wozniak, J.E.; Weiss, D.S. Methods to evaluate colistin heteroresistance in Acinetobacter baumannii. Methods Mol. Biol. 2019, 1946, 39-50. [CrossRef]

49. Peleg, A.Y.; Jara, S.; Monga, D.; Eliopoulos, G.M.; Moellering, R.C., Jr.; Mylonakis, E. Galleria mellonella as a model system to study Acinetobacter baumannii pathogenesis and therapeutics. Antimicrob. Agents Chemother. 2009, 53, 2605-2609. [CrossRef]

50. Palmieri, M.; D’Andrea, M.M.; Pelegrin, A.C.; Perrot, N.; Mirande, C.; Blanc, B.; Legakis, N.; Goossens, H.; Rossolini, G.M.; van Belkum, A. Abundance of colistin-resistant, OXA-23- and ArmA-producing Acinetobacter baumannii belonging to international clone 2 in Greece. Front. Microbiol. 2020, 11, 668. [CrossRef] [PubMed]

51. Olaitan, A.O.; Morand, S.; Rolain, J.M. Mechanisms of polymyxin resistance: acquired and intrinsic resistance in bacteria. Front. Microbiol. 2014, 5, 643. [CrossRef]

52. Cafiso, V.; Stracquadanio, S.; Lo Verde, F.; Gabriele, G.; Mezzatesta, M.L.; Caio, C.; Pigola, G.; Ferro, A.; Stefani, S. Colistin resistant A. baumannii: genomic and transcriptomic traits acquired under colistin therapy. Front. Microbiol. 2018, 9, 3195. [CrossRef]

53. Sun, B.; Liu, H.; Jiang, Y.; Shao, L.; Yang, S.; Chen, D. New mutations involved in colistin resistance in Acinetobacter baumannii. mSphere 2020, 5. [CrossRef]

54. Poole, K. Bacterial stress responses as determinants of antimicrobial resistance. J. Antimicrob. Chemother. 2012, 67, 2069-2089. [CrossRef] [PubMed] 
55. Andersson, D.I.; Hughes, D. Microbiological effects of sublethal levels of antibiotics. Nat. Rev. Microbiol. 2014, 12, 465-478. [CrossRef]

56. Da Silva, G.J.; Domingues, S. Interplay between colistin resistance, virulence and fitness in Acinetobacter baumannii. Antibiotics 2017, 6, 28. [CrossRef]

57. Farshadzadeh, Z.; Taheri, B.; Rahimi, S.; Shoja, S.; Pourhajibagher, M.; Haghighi, M.A.; Bahador, A. Growth rate and biofilm formation ability of clinical and laboratory-evolved colistin-resistant strains of Acinetobacter baumannii. Front. Microbiol. 2018, 9 , 153. [CrossRef]

58. Karakonstantis, S.; Saridakis, I. Colistin heteroresistance in Acinetobacter spp.: systematic review and meta-analysis of the prevalence and discussion of the mechanisms and potential therapeutic implications. Int. J. Antimicrob. Agents 2020, $56,106065$. [CrossRef] [PubMed]

59. Charretier, Y.; Diene, S.M.; Baud, D.; Chatellier, S.; Santiago-Allexant, E.; van Belkum, A.; Guigon, G.; Schrenzel, J. Colistin heteroresistance and involvement of the PmrAB regulatory system in Acinetobacter baumannii. Antimicrob. Agents Chemother. 2018, 62. [CrossRef]

60. Machado, D.; Antunes, J.; Simoes, A.; Perdigao, J.; Couto, I.; McCusker, M.; Martins, M.; Portugal, I.; Pacheco, T.; Batista, J.; et al. Contribution of efflux to colistin heteroresistance in a multidrug resistant Acinetobacter baumannii clinical isolate. J. Med. Microbiol. 2018, 67, 740-749. [CrossRef]

61. Hraiech, S.; Roch, A.; Lepidi, H.; Atieh, T.; Audoly, G.; Rolain, J.M.; Raoult, D.; Brunel, J.M.; Papazian, L.; Bregeon, F. Impaired virulence and fitness of a colistin-resistant clinical isolate of Acinetobacter baumannii in a rat model of pneumonia. Antimicrob. Agents Chemother. 2013, 57, 5120-5121. [CrossRef]

62. Jacobs, A.C.; Thompson, M.G.; Black, C.C.; Kessler, J.L.; Clark, L.P.; McQueary, C.N.; Gancz, H.Y.; Corey, B.W.; Moon, J.K.; $\mathrm{Si}$, Y.; et al. AB5075, a highly virulent isolate of Acinetobacter baumannii, as a model strain for the evaluation of pathogenesis and antimicrobial treatments. mBio 2014, 5, e01076-14. [CrossRef] [PubMed]

63. Li, J.; Yu, T.; Luo, Y.; Peng, J.-Y.; Li, Y.-J.; Tao, X.-Y.; Hu, Y.-M.; Wang, H.-C.; Zou, M.-X. Characterization of carbapenem-resistant hypervirulent Acinetobacter baumannii strains isolated from hospitalized patients in the mid-south region of China. BMC Microbiol. 2020, 20. [CrossRef]

64. Wang, C.H.; Hsieh, Y.H.; Powers, Z.M.; Kao, C.Y. Defeating antibiotic-resistant bacteria: exploring alternative therapies for a post-antibiotic era. Int. J. Mol. Sci. 2020, 21, 1061. [CrossRef] [PubMed]

65. Usai, D.; Donadu, M.; Bua, A.; Molicotti, P.; Zanetti, S.; Piras, S.; Corona, P.; Ibba, R.; Carta, A. Enhancement of antimicrobial activity of pump inhibitors associating drugs. J. Infect. Dev. Ctries. 2019, 13, 162-164. [CrossRef] [PubMed]

66. Monteiro, K.L.C.; de Aquino, T.M.; Mendonca Junior, F.J.B. An update on Staphylococcus aureus NorA efflux pump inhibitors. Curr. Top. Med. Chem. 2020, 20, 2168-2185. [CrossRef]

67. Trong Le, N.; Viet Ho, D.; Quoc Doan, T.; Tuan Le, A.; Raal, A.; Usai, D.; Sanna, G.; Carta, A.; Rappelli, P.; Diaz, N.; et al. Biological activities of essential oils from leaves of Paramignya trimera (Oliv.) Guillaum and Limnocitrus littoralis (Miq.) Swingle. Antibiotics 2020, 9, 207. [CrossRef] [PubMed]

68. Le, N.T.; Donadu, M.G.; Ho, D.V.; Doan, T.Q.; Le, A.T.; Raal, A.; Usai, D.; Sanna, G.; Marchetti, M.; Usai, M.; et al. Biological activities of essential oil extracted from leaves of Atalantia sessiflora Guillauminin Vietnam. J. Infect. Dev. Ctries. 2020, 14, 1054-1064. [CrossRef] [PubMed]

69. Amaral, S.C.; Pruski, B.B.; de Freitas, S.B.; Allend, S.O.; Ferreira, M.R.A.; Moreira, C., Jr.; Pereira, D.I.B.; Junior, A.S.V.; Hartwig, D.D. Origanum vulgare essential oil: antibacterial activities and synergistic effect with polymyxin B against multidrug-resistant Acinetobacter baumannii. Mol. Biol. Rep. 2020, 47, 9615-9625. [CrossRef] [PubMed]

70. Boonyanugomol, W.; Kraisriwattana, K.; Rukseree, K.; Boonsam, K.; Narachai, P. In vitro synergistic antibacterial activity of the essential oil from Zingiber cassumunar Roxb against extensively drug-resistant Acinetobacter baumannii strains. J. Infect. Public Health 2017, 10, 586-592. [CrossRef] [PubMed] 